\title{
Public and Private Production in a Mixed Delivery System: Regulation, Competition and Costs
}

\author{
Germà Bel \& Jordi Rosell \\ (Forthcoming in Journal of Policy Analysis and Management)
}

\begin{abstract}
Academics and policymakers are increasingly shifting the debate concerning the best form of public service provision beyond the traditional dilemma between pure public and pure private delivery modes, because, among other reasons, there is a growing body of evidence that casts doubt on the existence of systematic cost savings from privatization, while any competition seems to be eroded over time. In this paper we compare the relative merits of public and private delivery within a mixed delivery system. We study the role played by ownership, transaction costs, and competition on local public service delivery within the same jurisdiction. Using a stochastic cost frontier, we analyze the public-private urban bus system in the Barcelona Metropolitan Area. We find that private firms have higher delivery costs than those incurred by the public firm, especially when transaction costs are taken into account. Furthermore, tenders tend to decrease delivery costs.
\end{abstract}

Keywords: public-private, competition, transaction costs, mixed delivery, local governments JEL Codes: H0, H7, K00, L33

\section{INTRODUCTION}

Local governments in many developed countries have introduced competition and private delivery in the production of their public services. This has given rise to much discussion among both policymakers and scholars as they examine the relative merits of pure public and pure private forms of delivery. Owing to a lack of systematic cost savings from privatization (Bel, Fageda, \& Warner, 2010), scholarly analyses have shown a growing interest in alternative forms of service delivery that break with the traditional dichotomy between full direct service and complete contracting out. 
One alternative form of production is the mixed delivery system, under which public and private firms deliver the same service within the same local jurisdiction (Miranda \& Lerner, 1995). Recall that while sometimes "mixed delivery" is understood as public entities and private entities jointly producing a service by splitting production and delivery tasks, by "mixed delivery system" we mean here carving up a jurisdiction into sub units and then parceling out the same production and delivery process to different entities. Mixed delivery is fairly common in the U.S., with around 20 percent of local services over the last two decades being provided under mixed delivery, according to the regular surveys conducted by the International City/County Management Association-ICMA—(Girth et al., 2012; Warner \& Hefetz, 2008). Mixed delivery is frequent in such services as solid waste collection, nursing homes, and elderly care programs, among others (Miranda \& Lerner, 1995; Warner \& Hefetz, 2008). In contrast, mixed delivery is less frequent in Europe (Warner \& Bel, 2008). Indeed, European policymakers and scholarly literature prefer the term "mixed firm," an organizational form that differs from mixed delivery inasmuch as the government and its private partners share ownership of the firm (Cruz et al., 2014), which, moreover, is typically granted the monopoly provision of services in the jurisdiction. The model is also referred to as "partial privatization" (Bel \& Fageda, 2010)

Different types of benefit accruing from mixed delivery have been identified in the literature. Theoretical analyses, for example, stress that this system ensures failsafe delivery (Brown, Potoski, \& van Slyke, 2006; Miranda \& Lerner, 1995; Williamson, 1991), since governments retain material capabilities and know-how that facilitate the taking over of a contract should the private contractor perform poorly or the contract fail. While other private firms operating within the jurisdiction might also take over such a contract, this would probably entail lengthy negotiations and, moreover, private vendors are likely to be reluctant to intervene in such a process. Mixed delivery can also promote competition for the contract in the local 
market (Bel, Brown, \& Warner, 2014; Girth et al., 2012). While governments may promote competition via full privatization implemented through competitive tenders, many local public services are prone to market concentration and erosion of competition (Bel \& Costas, 2006; Bel \& Fageda, 2011). Thus, mixed delivery can help prevent monopolization by private firms (Miranda \& Lerner, 1995). However, these potential benefits must be weighed against a potential loss of efficiency if fragmenting the jurisdiction prevents profiting from scale or density economies, which may be relevant in several services.

Mixed delivery also reduces asymmetric information between government and private firms by benchmarking production processes and costs (Brown \& Potoski, 2006; Miranda \& Lerner, 1995), which reduces transaction costs (Brown, Potoski, \& van Slyke, 2008). Taking full advantage of these opportunities requires effective management, an essential factor for improving service delivery (Hill \& Lynn, 2004; Knott \& Payne, 2004; Meier et al., 2004). In this regard, the management requirements are dependent on whether mixed delivery is provided under competitive tender or under performance contracts, which involve more standard regulation (Albalate, Bel, \& Calzada, 2012).

While several scholars have analyzed the determinants of the choice of mixed delivery (Girth et al., 2012; Lamothe, Lamothe, \& Feiock, 2008; Warner \& Hefetz, 2008), there is a lack of empirical evidence on the effects that mixed delivery has on costs. To the best of our knowledge, Miranda and Lerner (1995) is the only study to date to have specifically addressed this issue. The authors conduct an empirical analysis of the effects of mixed delivery (or joint contracting) on aggregate expenditures, employment, and wages in a sample of U.S. municipalities, and find that cities with a higher percentage of services provided under mixed delivery incur lower expenditures than those with a higher percentage of direct production. Miranda and Lerner (1995, p. 199) suggest the need for future research "to assess the impacts of benchmarking by service function to inquire whether competition within the private sector 
is sufficient to promote cost savings without the need for duplication and/or overlap by instituting a production role for government."

The aim of this paper is to contribute to fill this gap in the analysis of the effects of the mixed delivery of local services on costs. More specifically, we compare the costs of public and private firms delivering the same service within the same local jurisdiction. Our analysis focuses on the Barcelona Metropolitan Area bus system, which is a notable case among the relatively few examples of the mixed delivery of local bus transit; a public firm and several private firms supply comparable urban bus services within the metro-area. This represents a unique opportunity to compare public and private delivery costs within the same jurisdiction by means of multivariate analysis. Additionally, and unlike most studies that compare private and public costs, our empirical analysis takes into account the transaction costs incurred when contracting out to private firms, which allows us to refine our analysis of the cost comparison. Note that a major advantage of analyzing different firms within a single jurisdiction, as opposed to studies elsewhere that draw comparisons between different cities (or even different countries), is that we do not need to rely on the assumption of homogeneity of regulators and spatial homogeneity.

\section{RELATED LITERATURE ON PUBLIC-PRIVATE DELIVERY AND COSTS}

While examples of successful service delivery contracts can be found, the outcomes of such contracts have in many cases been disappointing. In this debate, a growing body of evidence appears to cast doubts on the existence of systematic and sustainable cost savings attributable to privatization (Bel, Fageda, \& Warner, 2010; Bel \& Warner, 2008). The main explanations offered for these mixed findings are differences in the transaction costs of contracted and direct services (Brown \& Postoski, 2003a, 2003b, 2005; Levin \& Tadelis 2010), geographical differences in the availability of private providers (Hirsch, 1995; Warner \& Hefetz 2002, 2003), 
and trends towards concentration and diminishing competition over time (Bel \& Costas, 2006; Bel \& Fageda, 2011).

Transaction costs are a key issue in the debate concerning potential cost savings from privatization, and have become a regular focus in the literature on public service privatization since the seminal studies of Sappington and Stiglitz (1987) and Williamson (1991, 1999). Contracting procedures are costly, as are the monitoring and supervision of contracted services. Brown and Potoski (2003a, 2003b, 2005) show that transaction costs have a marked influence on the privatization of local services, and identify the importance of two dimensions related to transaction costs: asset specificity and ease of measurement. ${ }^{1}$ In the case of urban bus services, asset specificity can be related to investments in buses and, especially, in bus depots. On their side, ease of measurement can be related to monitoring the passengers transported, travel times, etc. Contracting agencies may underestimate the costs of the overall process as transaction costs are often excluded from the analysis. However, transaction costs have received very little attention in the empirical analysis of public and private deliveries.

The role of the spatial dimension of competition in the provision of local public services was taken into consideration by Warner and Hefetz (2002, 2003), who showed that different geographical areas (e.g., rural vs. urban) are characterized by differences in the respective availability of private vendors and so offer dissimilar prospects for competition. Indeed, the geographical area seems to be a critical determinant of the level of market competition. Bel and Fageda (2011), for example, report that the number of firms bidding for contracts in smaller cities is lower than that in larger cities, and also that competition is eroded over time. Furthermore, Bel and Costas (2006) show that this erosion of competition is a key factor in accounting for the lack of differences in costs between public and private delivery. In the same vein, Girth et al. (2012) find a positive correlation between the choice of delivery form and the level of competition in metro core areas. They also obtain interesting qualitative results on the 
dynamics of government "relational contracting": regulators tend to devote more time and resources in building and sustaining competition because a low level of competition tends to add to transaction costs.

Mixed delivery is a production choice that escapes the classical dilemma between full direct production and complete contracting of services. Regulators can compare the firms' respective production processes and costs, while retaining direct involvement in service delivery. Mixed delivery allows a government to divide its jurisdiction in several areas, with pure public delivery being used in one or more areas and pure private production in other district(s) within the same jurisdiction (Warner \& Bel, 2008). Miranda and Lerner (1995) claim that this "redundancy" or duplication in delivery methods may in fact be efficient (as was proposed earlier by Landau, 1969), as a form of benchmarking with the private sector, and as a means of promoting bureaucratic competition in house. As such, mixed delivery can promote competition by means of introducing competitive pressures on public firms, i.e., by disciplining public managers and labor unions (Hatry, 1999; Miranda \& Lerner, 1995), and by preventing private firm monopolization (Miranda \& Lerner, 1995). The rise in mixed forms of delivery reflects a continuing process of change and innovation at the local government level that combines the benefits of both market and public delivery (Warner \& Hefetz, 2008): private firms are interested in profit and efficiency; the public sector is also interested in efficiency, but it is also expected to provide failsafe delivery and a higher level of public accountability and involvement.

Evidence on mixed delivery and costs is scarce, as mentioned in the introduction. With respect to the expectation that mixed delivery will provide lower costs than those associated with complete direct delivery, Miranda and Lerner (1995) obtained empirical evidence consistent with that hypothesis. Concerning our analysis, two hypotheses can be emphasized: 
(1) Mixed delivery is expected to provide balanced costs between public and private providers, because the system disciplines the public production that is retained.

(2) Mixed delivery is expected to improve competition for contracts, allowing for a reduction in costs via the tendering process.

Our paper seeks to enhance current understanding of the implications of mixed delivery for costs, and makes two major contributions to the literature. First, we analyze cost differences between public and private firms under a mixed delivery regime, and analyze whether tendering processes help to reduce delivery costs. Second, and unlike traditional cost comparisons between public and private providers, we explicitly include the transaction costs incurred by the regulatory agency (contracting procedures plus monitoring and supervision of contracted services) in the cost comparison, which allows us to refine the cost analysis for different types of service delivery.

\section{EMPIRICAL EVIDENCE ON PUBLIC AND PRIVATE DELIVERY COSTS AND TENDERS IN LOCAL BUS SERVICES}

Early studies of the impact of privatization on urban bus services typically reported cost savings and greater efficiency with private delivery, for example, in the U.K. (Savage, 1993; White, 1997), New Zealand and Chile (Lee \& Rivasplata, 2001), and Switzerland (Filippini \& Prioni, 2003). While almost none of the research published before 2000 took competition into account in their empirical analyses (De Borger, Kerstens, \& Costa, 2002), more recent studies have controlled for competition for the contract. Leland and Smirnova (2009) compared the evolution in efficiency and effectiveness of U.S. urban bus services, and found that privately owned and managed transit systems were no longer more efficient and effective providers than government-owned agencies. They pointed to the lack of competition between contractors and 
higher transaction costs as factors. Recall that the market for bus services is imperfectly contestable (Mackie, Preston, \& Nash, 1995).

The most common means of introducing competition in the provision of urban bus

services is through competitive tendering. ${ }^{2} \mathrm{~A}$ trans-European study found that public firms are less productive than private ones, while firms selected through competitive tendering are more productive (Boitani, Nicolini, \& Scarpa, 2013). However, the most telling result is that during the second round of the tendering process (some years after the first), an increase in the gross cost is recorded in most countries. Not only are there no sustained cost savings, but there is also some deterioration in the quality of the service provided, especially when the incumbent is replaced by a new entrant (Mouwen \& Rietveld, 2013).

Falls in the number of bidders and in bus market concentration have been described in Sweden (Alexandersson, Hultén, \& Fölster, 1998), France (Yvrande-Billon, 2006) and Norway (Mathisen \& Solvoll, 2008). This situation is paralleled in Italy, where the incumbent operator tends to win most tender processes (Boitani \& Cambini, 2006). ${ }^{3}$ Hensher and Wallis (2005) express a concern that tendering is open to regulatory capture by powerful monopolist bus providers. Consequently, putting this relationship out to tender, in a process that attracts few bidders and involves complex contracts and incompleteness, may not be the best solution when compared to negotiated performance-based contracts (Hensher \& Stanley, 2008). Hensher (2015) concludes that the gains from competitive tendering are generally illusory or overstated (outside the situation of an incumbent public firm). ${ }^{4}$

\section{INSTITUTIONAL CONTEXT: THE BARCELONA METROPOLITAN BUS SYSTEM, REGULATORS AND OPERATING COMPANIES}

The provision of public transport in the Barcelona Metropolitan Area has remained largely stable over recent decades. Local bus transit is provided under a mixed delivery system, in 
which one public firm (Transports Metropolitans de Barcelona-TMB) and several private firms supply the service in different areas, these last under the supervision of a regulator (Entitat Metropolitana del Transport-EMT). Recall that empirical analyses of urban bus systems report U-shaped average cost functions. In other words, and as suggested earlier by Berechman (1993), economies of scale are constant or even revert to decreasing returns to scale as firms grow in size (Jørgensen, Pedersen, \& Volden, 1997; Matas \& Raymond, 1998). This is an important outcome for the management of local bus systems, because it implies that the service can be fragmented in large cities between different firms, without foregoing any of the potential benefits of scale economies.

The EMT is responsible for regulating local bus transit in the city of Barcelona and the towns in its metropolitan area. Private companies can operate services by means of competitive tendering contracts (net-cost contracts) or negotiated performance-based contracts (gross-cost contracts), both with quality incentives. The EMT defines the characteristics of the service offered by the concessionaires, establishes network routes, draws up bus schedules, defines quality levels, organizes the tenders, and covers the deficits run up by the private firms ${ }^{5}$ (Albalate, Bel, \& Calzada, 2012). EMT has considerable experience as a management contractor and has been tendering services since the 1990s. The EMT is the owner of bus fleets and bus depots, and provides vehicles and facilities to the operating companies. Recall that this reduces potential asset specificity problems, since it minimizes problems related to sunk costs, thus increasing market contestability.

The publicly owned firm TMB operates 106 lines, and in 2012 it carried around 174 million passengers. The number of passengers has remained stable since 1980, as several lines formerly operated by TMB have been privatized, and the metropolitan subway network has also been expanded. Correspondingly, supply has also remained quite stable: TMB offered 3,182 million seats-km in 2012, just a little above the 3,050 million seats-km supplied in 1989. TMB 
has not participated in any tender process in the Barcelona Metropolitan Area. ${ }^{6}$ TMB enjoys freedom to design and plan its own services, and is not subject to a concession contract with the EMT. As such, TMB can be described as a corporatized company, enjoying greater managerial flexibility than that typically enjoyed by a traditional bureaucratic organization. Note that the public entity is essentially unregulated and has a much freer hand to make management decisions than the private firms, which are heavily regulated by EMT.

Several of the private concessions overlap with the TMB delivery area as both connect Barcelona (including downtown) with the surrounding municipalities and also operate in these surrounding municipalities. The only difference is that TMB operates the intra-city routes. Bus services operated by private firms under competitive contracts represent 81 percent of EMT's total passengers (excluding TMB). Private concessionaires that win tenders operate under netcost contracts, with vehicle and depot facilities being supplied by the EMT.

Tender concessions follow a net-cost contract scheme or a minimum subsidy: firms receive a subsidy from the EMT that is equal to the difference between the expected revenues from passengers and the bidding cost. Private operators enjoy far less managerial autonomy than TMB. However, there are revenue incentives related to such factors as extra-passengers, punctuality, vehicle quality and passenger's perceived quality, among others. These revenues represent around 4 percent of total revenues (excluding subsidy). Average concession length is five years, with the possibility of an extension (average length of extensions is three years).

\section{Tendering Processes}

The first tendering process took place in 1998. Table A1 in the appendix ${ }^{7}$ displays all the tendering processes implemented up to and including 2012, and which are considered in our analysis. The number of firms bidding to obtain a concession has varied from between two and five. ${ }^{8}$ Table A1 also includes the negotiated performance-based contracts, all of which are held by two firms belonging to the same metropolitan-based group (Baixbus). Note that we do not 
include negotiated performance-based contracts in our empirical analysis as the services delivered under them are of a different nature from those produced directly or tendered; and, more importantly, because the firms holding these contracts are under no obligation to report any data to the regulator. As a result, no specific firm data are available, whereas data from firms that have won tenders are available.

The majority of private firms offering services operate according to the concession awarded in the corresponding tendering process. A small number of firms concentrate the market for tendered services, even though there were several bidders in the contests. It is worth noting that no "outsiders" (that is to say, firms or groups based outside the Barcelona Metropolitan Area) have ever won a tender, even when requesting the lowest subsidy (lowest contract price). That points to the existence of relational considerations or rent-seeking costs; that is, the regulator has incentives to avoid changing the firm because the day-to-day relationship would change. For example, unexpected changes not provided for under the contract might be harder to implement. A further possibility is that the regulator expects the incumbent to provide a higher quality service; and, so, prefers to maintain the contractual partner.

\section{EMPIRICAL STRATEGY: STOCHASTIC COST FRONTIER FOR PANEL DATA}

A firm converts inputs into output. Thus, a bus company uses employees as labor force, and fuel and other materials to obtain energy to cover kilometers and transport passengers, assuming the total variable cost to be a function of input and conditional to the level of capital provided by the authority. Beyond this specification, several authors also identify network characteristics such as the length of the line or the average speed (see De Borger, Kerstens, \& Costa, 2002, for a detailed review). Another group of factors that influence operating costs are the form of 
ownership, competition, and other environmental characteristics. The total variable cost frontier can be written as the following function:

$$
\mathrm{TVC}_{i t}=f\left(Y_{i t}, P L_{i t}, P M_{i t}, K_{i t}, N_{i t}, O_{i t}, t\right)
$$

where the total variable cost of an urban bus line TVC is assumed to be a function of output $Y$, factor prices $P$ (labor $L$ and material and energy $M$ ), capital $K$, the network characteristics $N$, the competition and ownership $O$ and the time trend $t$, among others. The model takes the urban bus line's variable cost as a dependent variable; that is, its total annual operating expenses. It is important to note that variable costs exclude fixed capital costs, i.e., the cost of vehicles and bus depots, which in many cases are funded entirely_or almost entirely—by the government or the regulator. This is, in fact, the case in the jurisdiction we analyze here. Thus, capital represents a quasi-fixed input. Variable costs are increasingly being used in the empirical analysis of costs in order to deal with an apparent paradox: the very frequent finding, and a common result in the literature on buses, of a negative coefficient for capital costs when using capital as an input price. This result is due to a non-cost minimization process for capital (see, for example, Cambini, Piacenza, \& Vannoni, 2007), because in many cases the government or regulators cover these costs in full or almost in full. This is the case, for instance, in France; and for this reason, Gagnepain (1998) opted to use variable costs instead of total costs. As mentioned, variable costs are increasingly being used in the literature as the dependent variable and have become the standard choice in the most recent empirical studies (e.g., Ayadi \& Hammami, 2015). Therefore, in this framework, because the operators do not minimize the cost of capital, we expect a negative sign.

When data are comparable and consistent over time, the most frequently occurring functional form in the literature is a translog cost function (Coelli, 2003). This function was first proposed by Christensen et al. (1973) and was first applied to urban bus transit by Viton 
(1981). Subsequently, it has been applied in many empirical studies on this field. ${ }^{9}$ The cost function equation to be estimated can be expressed in the following double log form:

$$
\begin{aligned}
& \ln \frac{T V C_{i t}}{P M_{i t}}=\beta_{0}+\sum_{x=Y, N, S P, \frac{P L}{P M}, K} \beta_{x} \ln x_{i t}+\sum_{x=Y, N, S P, \frac{P L}{P M}, K} \frac{1}{2} \beta_{x}^{\prime}\left(\ln x_{i t}\right)^{2}+ \\
& \sum_{\substack{x, x^{\prime}=Y, N, S P, \frac{P L}{P M^{\prime}, K} \\
x \neq x^{\prime}}} \beta_{x} \ln x_{i t} \ln x_{i t}^{\prime}++\beta_{21} T E N D_{i t}+\beta_{22} P R I V_{i t}+\beta_{23} T U S_{i t}+\beta_{24} R O S_{i t}+
\end{aligned}
$$

$\beta_{25} S_{O L}+\beta_{26} B A R C_{i t}+\beta_{27} M_{E T R} R_{i t}+\beta_{28} M U N_{i t}+\beta_{29} T I M E_{t}+\xi_{i t}$

with $i=1,2, \ldots, 42$ and $t=2002,2003, \ldots, 2012$

where subscripts $i$ and $t$ denote the line and year, respectively. The dependent variable is Total Variable Costs (TVD). The output variable (Y) is the vehicle-kilometers, $\mathrm{N}$ is the network length, $\mathrm{SP}$ is the average speed, the price of labor $(\mathrm{PL})$ is related to the price of materials $(\mathrm{PM})$ and the capital $(\mathrm{K})$ is the number of buses per line. TEND is the year of tender for private concessions, PRIV is a dummy for private lines and TUS, ROS and SOL are dummies for private concessions. The control variables are BARC for lines inside the city of Barcelona while METR is a dummy indicating whether or not a new metro station has been opened near to a bus line and MUN is a dummy indicating whether or not the bus routes are within the same municipality. TIME is a yearly time trend variable. $\xi_{i t}$ is the random term divided in $v_{i t}$ (normally distributed) and $u_{i t}$, the inefficiency term (half-normally distributed). Table 1 reports the definitions and expected outcomes for all the variables. The dependent variable and the labor input have been divided by materials input price. In addition to the standard variables of a proper cost function, we included network length $(\mathrm{N})$ and average commercial speed (SP) in the model, in line with Levaggi (1994) and Gagnepain (1998). ${ }^{10}$

\section{(Table 1 around here)}

Our main objective is to analyze the ownership and competition variables. The ownership issue has been analyzed in the literature; however, the results regarding the 
relationship with efficiency and productivity in the private sector are inconclusive. Year of tender is an innovative variable for detecting the impact of a tender process as a competitive mechanism. We include three control variables: Barcelona, which controls for lines inside this city; municipality, which controls for lines within a municipality other than Barcelona; and, metro, which controls for subway stations opened near a bus stop on a specific line.

We use cost frontiers for panel data, as first introduced by Battese and Coelli (1988). We select two different models: the Battese and Coelli model (1992) and the True Random Effects model (Greene, 2005). There are different distributional assumptions to create an empirical model from the "composed error." The first of these models assumes a random component term to be time variant, so that $t$ is different from $T_{i}$ (Battese \& Coelli, 1992). The decay parameter $-\eta$ shows the temporal pattern of inefficiency.

$$
u_{i t} \equiv \exp \left\{-\eta\left(t-T_{i}\right)\right\} u_{i}
$$

We assume that $v_{i t} \sim N\left(0, \sigma_{v}^{2}\right)$ and $u_{i t} N^{+}\left(0, \sigma_{v}^{2}\right)$. Battese and Coelli's (1992) panel data model is somewhat restrictive because it only allows inefficiency to change over time exponentially. Nonetheless, this model allows exploiting better the panel structure of the data. When estimating the inefficiency measures, one of the main problems faced is avoiding the unobserved heterogeneity bias. Based on their findings, Farsi, Filippini and Kuenzle (2006) propose potential differences in cost frontier parameters and inefficiency scores. As such, True Random Effects could perform better, allowing line-specific heterogeneity to be captured. This model is particularly suited to transport industries where network and environmental traits (time-invariant factors) are mostly unobserved but play an important role in operating costs (Farsi, Filippini, \& Kuenzle, 2006). To calculate inefficiency scores, the value of $u_{i t}$ needs to be positive. Indeed, the model predicts they will be positively skewed in cost frontiers. Thus, lambda $\left(\lambda=\frac{\sigma_{u}}{\sigma_{v}}\right)$ indicates the ratio of the standard errors of the inefficiency terms to the 
standard deviation of the stochastic term (Greene, 2005, 2008). If the estimate of $\lambda$ is statistically significant, that suggests evidence of cost inefficiency in the data.

The actors affected by transaction costs are the private firms and the regulator. Private companies need to devote some of their time to preparing their tender bid and to working with the regulator if they win the contest. ${ }^{11}$ The regulator, on the other hand, has to organize the tender process and monitor the private winner during the period of concession. However, the regulator's budget is paid for by the taxpayers, and there is no specific transfer of the regulator's costs to the private firm's services. Our paper is, to the best of our knowledge, the first to consider the regulator's transaction costs. As EMT would not need to exist if there were no private firms operating in the jurisdiction, we take the regulator's budget (which is publicly available) as our measure of the transactions costs not internalized by the firms. Then, we allocate the regulator's costs equally among all the private lines, which allows us to provide a more refined and robust cost comparison. Later, in the section dedicated to the robustness check, we consider an alternative cost allocation method: the number of passengers carried by each line. ${ }^{12}$

\section{DATA}

The data set is an unbalanced panel for the period 2002 to 2012, comprising 405 observations and four companies, one of them fully publicly-owned (TMB) and the other three completely private. Data are provided by the public bus company (TMB) and the regulator (EMT), the later providing data for the private firms.

We choose private bus lines that connect Barcelona with neighboring towns and urban lines in surrounding towns in areas under concession. ${ }^{13}$ We exclude lines that run parallel to motorways or high capacity roads, since the characteristics of these lines are not similar to those operated by the public company TMB. We choose all TMB lines that connect Barcelona with 
neighboring towns, as well as lines within the municipality of Barcelona but at some distance from downtown Barcelona. We exclude all night routes because they differ markedly from day routes in terms of wages paid, average speed, network length, etc. In this way, we make sure we are analyzing homogeneous lines.

Table 2 reports summary statistics for the concessionaire firms included in the analysis. The available information includes - for each concession - the number of lines analyzed, the line length, the number of passengers carried, the number of vehicles, the number of employees, and the cost and revenue per net $\mathrm{km}$ (thus, we do not take into account trips made without passengers from and to bus depots; hereafter, "per km"), among others. The main differences between the concessionaires concern the number of lines analyzed, the number of passengers carried, the number of vehicles and the costs, total costs and the cost per km covered.

\section{(Table 2 around here)}

More than half the lines analyzed are publicly managed, while the others are distributed among the three private companies. Differences also occur between the public and private companies in terms of the cost per $\mathrm{km}$, the number of passengers carried and the number of kilometers covered. Given the similarity in line length, it is clear that TMB has a higher bus frequency than that operated by the private companies. The number of employees is higher and significantly different in the public company compared to the private firms. But the public company also carries more passengers. Because of this, some private companies employ a larger workforce than that employed by TMB relative to the number of kilometers covered. There are marked differences in costs: TMB is the most expensive firm by line, but when we compare the total variable costs by $\mathrm{km}$ covered, it is not the most expensive. The transaction costs for the private lines remain constant each year. However, these costs can represent between 3.5 and 14 percent of their total costs. 


\section{RESULTS}

First, we estimate a stochastic cost frontier for panel data using Battese and Coelli (1992). Table

3 shows the results (see second order coefficients in Table A2 in the Appendix). ${ }^{14}$ For concession dummies we take as our reference TMB. All variables are expressed in logarithms (with the exception of the dummy variables); therefore, coefficients can be interpreted as elasticities. The original values of the monetary variables are deflated by a price index.

\section{(Table 3 around here)}

Half of the specifications are estimated with the dependent variable (total variable cost) without including the transaction costs (left-hand columns), while the other half include the transaction costs (right-hand columns). Overall, no significant differences were found when using either one or other of the alternative specifications for the dependent variable, with the exception of the effect of tenders on costs.

In general, the main variables present the expected sign and are statistically significant. Furthermore, the coefficients are within usual results, and have small variability throughout estimations. This is particularly so for the core variables in our study, those reflecting ownership, firm, and competition, where our core contributions lie. Output elasticity provides the only relevant exception, as it shows large variability: between 0.311 and 1.295 , implying that a 1 percent increase in the bus vehicle-kilometers supplied will increase total costs by just 0.311 percent to 1.295 percent. ${ }^{15}$ Average speed is negative or non-significant and our findings confirm that it is negatively related to a firm's cost performance. Therefore, public policies oriented towards increasing bus transit speeds might be desirable, because passengers (or taxpayers) would pay less for bus transportation. By contrast, network length is positive and significant or non-significant, as expected, although the result is not statistically significant in non-transaction cost estimations. 
In the case of labor input price, which appears to be significant in all specifications, coefficients vary between 0.84 and 0.54 , in line with usual results elsewhere in the literature. The coefficient for (quasi-fixed) capital is negative and highly significant, ranging from -1.58 to -0.33 , which means that a greater availability of buses (paid for by the EMT) would bring about a reduction in total variable costs. While the available evidence shows divergent results for this variable, our results are in line with those reported, for instance, by Obeng (1985) and by Gagnepain (1998), and they have solid theoretical foundations, as discussed in Gagnepain (1998) and Croissant, Roy, and Canton (2013). The coefficient of the linear time trend is significant and negative in all models; thus, technological progress is significant in Barcelona's local bus industry. The control variables are mostly non-significant; thus, we do not find any differences between interurban lines and intra-municipal lines (Barcelona and municipality dummies). Likewise, the new subway services do not exert any competitive pressure on the bus lines (metro dummy). The value of lambda indicates the right skewness of the inefficiency term in three of the four specifications.

Our primary focus is, first and foremost, to compare the costs of public and private delivery. Interestingly, we do not find any cost savings with private delivery. In fact, private firms appear to have higher costs than those incurred by the public firm, this being true for all estimations, without and with transaction costs. Indeed, cost differences are more marked when transaction costs are taken into account.

Second, we are interested in determining the effects of competition on costs. Here, the year of tender shows a negative and significant impact on costs, although non-transaction cost specifications show a non-significant result. In this regard, our results are relatively consistent with our second hypothesis-we expected stronger competitive pressures in the tender processes to result in cost reductions, especially when transaction costs are taken into account. 
We replicate our model using the True Random Effects model as proposed by Greene (2005). True Random Effects separate firm effects from inefficiency. Recall that one limitation of this model is that the line's inefficiency is uncorrelated with the explanatory variables and is assumed to be constant over time. In relatively long panels, and even in those cases in which the management's efficiency is constant, technical efficiency varies over time. Table 4 shows the results (see second-order coefficients in Table A3 in the Appendix). ${ }^{16}$

\section{(Table 4 around here)}

We obtain very similar results (sign and significance) for all variables in the equation, although estimation 5 shows somewhat contradictory results for line length and speed. Focusing on our key variables, we find, in relationship to ownership, that private lines are always more costly than public lines, except in one specification for which there is no statistical difference. In the case of the second hypothesis, we obtain cost decreases related to the tender process in three estimations, and no significant effect in one. Here, it is worth noting that we also considered the year of tender variable as a dummy variable with a value of one for all years following the tender process and 0 otherwise. Tender mechanisms lowered costs for all specifications.

One objective in fitting the frontier models is to estimate the inefficiency terms. In Table 5 we provide the inefficiency estimates for all specifications for the three different models. The interpretation of these coefficients is the excess variable costs of a line compared to the costs of the most efficient performer in our data. In all lines specifications, the inefficiency estimates fall within a realistic range. We perform the Kruskal-Wallis test for each specification by dividing the sample into public and privates lines. The main result for the majority of specifications is the statistical significance of the better performance of public as opposed to private lines. For some True Random Effects estimations, there is no statistical difference of the better performance of public compared to that of private lines. Note, however, that these 
specifications include ownership variables, so this variability is captured. All in all, public lines are more efficient than their private counterparts. ${ }^{17}$

(Table 5 around here)

\section{ROBUSTNESS TESTS}

In this section, we perform several robustness tests. First, we regress the model using a different approach to transaction costs in order to test different ways of allocating these costs; the definition of the model and all independent variables remain exactly the same, contrary to what happens to our dependent variable: Total variable costs (including transaction costs). Recall that in our analysis above we applied an egalitarian allocation of transaction costs (based on lines). Here, instead, we apply a non-egalitarian allocation: we allocate those transaction costs based on the different effort or time spent by the regulator in monitoring each private line. Effort and time will depend on the complexity of the line, and we take as an indicator for complexity the number of passengers carried by each line. Thus, for each year we allocate transaction costs based on the ridership of each line (proportional to the number of passengers carried). We use the same models as above; namely, the Battese and Coelli (1992) model and True Random Effects. Table 6 shows the results.

\section{(Table 6 around here)}

In the case of our key variables, we obtain the same results as those obtained in all the previous models for the ownership variable: private lines are more costly than public lines. In the case of the tender variable, a negative and significant coefficient is found for all specifications. Adopting different methods to allocate the transaction costs does not bring about relevant changes in the variables related to ownership and the tender processes. All in all, our results show remarkable stability across all the robustness tests. 
The estimate of $\lambda$ is statistically significant in most specifications, suggesting evidence of technical inefficiency in the data. We provide separate inefficiency measures from the Battese and Coelli and the True Random Effects models (Table 7) for the public and private lines. Inefficiency estimates stand at around 0.01 to 0.03 (in line with the available evidence), ${ }^{18}$ which represents a potential cost saving of between 1 and 3 percent. The public-private comparison shows a better performance of public lines according to the Kruskal-Wallis test.

\section{(Table 7 around here)}

The second robustness test relates to the specification of the competition variable. In our analysis above, we specified competition as a dummy with value 1 the year following a tender, and 0 otherwise. Here, instead, this independent variable (everything else remains equal) takes a value of 1 for all years after the tender process and 0 otherwise. We perform the same specifications (allocating transaction costs by number of passengers per line) as in the previous robustness tests. Table 8 displays the results (second-order coefficients in Table A4 in the Appendix). ${ }^{19}$ The competition variable is also negative for all specifications. This indicates that our results are robust to different specifications. Moreover, the ownership variables are always significant; the private lines are more costly than the public lines.

\section{(Table 8 around here)}

\section{DISCUSSION}

Throughout our empirical exercise, we find that public delivery costs are lower than private costs, and the cost advantage of public delivery further increases when transaction costs are considered, as could be expected. In this regard, our results are not in line with the expectation that public and private firms will face similar costs with mixed delivery. Furthermore, our results show the importance of considering transaction costs, as they reflect the costs paid by the citizens to maintain the regulator, and they ensure a better comparison of the total costs paid 
by bus users and taxpayers. The failure to consider transaction costs in previous empirical studies may well have biased the results of the cost comparisons undertaken to the detriment of public firms.

It is worth emphasizing as well that tenders for concessions tend to contribute to decrease costs. Thus, our findings provide support to expectations that mixed delivery results in more competitive tenders. Our results show that competition between private firms is effective and that private firm delivery is more costly, particularly when we take into account their transaction costs.

Governments and regulators face different challenges. First, they have to fulfill the requirements of competitive tendering that emanate from higher legal frameworks promoting contests in which there is no common carrier providing the service. Second, they are forced to seek more flexible agreements to guarantee a workable relationship based on trust with the private operator. This is particularly so if, as Heinrich and Marschke (2010) suggest, we take into account the fact that incentives should be used for agents that are responsive to them, and that procedures and regulations affecting bureaucracies or public firms can constrain them more than they constrain private firms. ${ }^{20}$

Competitive tendering involves greater rigidities than a negotiated contract, since it reduces government opportunities for modifying the delivery conditions. These rigidities may be weakened somewhat by changes introduced by the regulator into the contract. The big rate of new contracts awarded to incumbents—quite common, as shown in Boitani and Cambini (2006), Beck and Walter (2013), etc.-suggests a partnership of trust exists between the regulator and private operators. All this seems to indicate that competitive tendering conditions are increasingly tending to resemble a negotiated performance-based contract, as observed. In this context, regulator accountability is weakened. 
However, private production (supply from private vendors) within a mixed delivery system may also be used as the basis for a credible threat for the privatization of some publicly delivered services. Indeed, this threat has been used in Barcelona at the time of labor conflicts within the TMB (Albalate, Bel, \& Calzada, 2012, p. 97). As such, it may have contributed to cost containment in the public firm, thus helping to explain its relatively good economic performance (compared to that of the private firms) in Barcelona.

\section{CONCLUSION}

In this paper we have evaluated the impact of firm ownership and competition on the total variable costs of a local bus transit service within a mixed delivery regime, paying particular attention to the presence of the transaction costs involved in private delivery. We have estimated a translog stochastic cost frontier in an attempt at shedding light on the effect of the delivery choices. The main results can be summarized as follows.

First, public delivery has been found to perform better than the private operators selected via competitive tendering. The public company provides bus services at a lower cost to that incurred by the private companies, and differences in cost increase when we take into account transaction costs. This result is a clear indication that cost comparisons that ignore transaction costs may well be underestimating private costs and giving a misleading picture of the costs associated with public and private delivery.

Second, we find evidence that operating under tender procedures implies cost savings in the private segments of the service, because the tender process tends to affect variable costs. However, potential savings from tenders are not large enough to offset higher costs incurred by private firms when compared to public delivery. A possible explanation is the existence of relational contracting due to complex contracts and incompleteness. The regulator might prefer to establish strong relationships based on trust with specific private providers because it needs 
to make constant changes to the contract. In this regard, it is important to emphasize that maintaining public delivery helps the government to better understand the real costs of services, thereby mitigating information asymmetries.

The debate on the reform of public service delivery has most frequently focused on the dilemma between pure public and pure private delivery modes. Our analysis suggests that mixed delivery (as long as economic conditions for service fragmentation exist) creates a framework in which policymakers and regulators can employ different tools to pursue different objectives; for instance, using the more flexible management practices of private firms to adjust to non-contractual events or to unforeseen needs. Note, however, that this greater flexibility can result in higher costs being incurred by the regulator, which casts doubts on whether mixed delivery is used as an overall cost minimizing strategy.

We are aware that the generalization of our results is by no means straightforward: first, we analyze a specific service in a specific jurisdiction (that of Barcelona) and, second, while the number of mixed delivery systems is increasing, they are far from usual in the organization of the delivery of public services in local public transportation. This said, our findings should prove useful beyond the specific case of local bus services and be of relevance in other services where mixed delivery is frequent, in particular, those services, such as solid waste collection, where transportation is a major characteristic of the service. Clearly, future research needs to devote more attention to analyzing in greater depth the characteristics and effects of mixed and hybrid delivery choices. Likewise, further empirical studies of mixed delivery in other services would enhance our knowledge of its advantages and drawbacks.

GERMÀ BEL is a Professor of Economics in the Department of Econometrics, Statistics and Applied Economics, University of Barcelona, John Keynes 1-11, Barcelona 08034, Spain, and Research Associate at GiM-IREA (e-mail: gbel@ub.edu; home page: http://www.germabel.cat ).

JORDI ROSELL is a Lecturer in the Department of Econometrics, Statistics and Applied Economics, University of Barcelona, John Keynes 1-11, Barcelona 08034, Spain, and Research Associate at GiM-IREA (e-mail: jrosell@ub.edu; home page: www.jordirosell.com/). 


\section{ACKNOWLEDGMENTS}

This research received support from the Spanish Government (project ECO2012-38004), and the Regional Government of Catalonia (project SGR2014-325). Germà Bel acknowledges support from ICREA-Academia. Jordi Rosell acknowledges support from Societat Econòmica Barcelonesa Amics del País. Comments and suggestions received when the paper was presented at the XXI Spanish Conference on Public Economics in Girona and the XXXIX Symposium of the Spanish Economic Association in Palma de Mallorca have been very helpful. We are particularly thankful to Humberto Brea, Trevor Brown, Marc Esteve, Philippe Gagnepain, Pelayo González, Emili Grifell-Tatjé and Diego Prior for very useful insights. We are thankful to Transport Metropolitans de Barcelona, particularly to Joaquim Forn, Cinto Soler and Gabriel Sansa, and also to Pelayo Martínez, Maria Teresa Carrillo and Eduard Unzeta (Metropolitan Transport Area-AMB) for providing information to carry out our empirical analysis. Finally, we have benefited from comments and suggestions by the editor and several anonymous referees.

\section{REFERENCES}

Albalate, D., Bel, G., \& Calzada, J. (2012). Governance and regulation of urban bus transportation: Using partial privatization to achieve the better of two worlds. Regulation \& Governance, 6, 83-100.

Alexandersson, G., Hultén, S., \& Fölster, S. (1998). The effects of competition in Swedish local bus services. Journal of Transport Economics and Policy, 32, 203-219.

Ayadi, A., \& Hammami, S. (2015). An analysis of the performance of public bus transport in Tunisian cities. Transportation Research Part A: Policy and Practice, 75, 51-60.

Battesse, G. \& Coelli, T. J. (1988). Prediction of firm-level technical efficiencies with a generalized frontier production function and panel data. Journal of Econometrics, 38, 387399. 
Battesse, G. \& Coelli, T. J. (1992). Frontier production functions, technical efficiency and panel data: With application to paddy farmers in India. Journal of Productivity Analysis, 3, 153169.

Beck, A. \& Walter, M. (2013). Factors Affecting Tender Prices in Local Bus Transport Evidence from Germany. Journal of Transport Economics and Policy, 47, 265-278.

Bel, G., Brown, T., \& Warner, M. E. (2014). Mixed and Hybrid Models of Public Service Delivery. International Public Management Journal, 17, 297-307.

Bel, G. \& Costas, A. (2006). Do public sector reforms get rusty? Local privatization in Spain. Journal of Policy Reform, 9, 1-24.

Bel, G. \& Fageda, X. (2010). Partial privatization in local services delivery: An empirical analysis on the choice of mixed firms. Local Government Studies, 36, 129-149.

Bel, G. \& Fageda, X. (2011). Big Guys Eat Big Cakes: Firm Size and Contracting In Urban and Rural Areas. International Public Management Journal, 14, 4-26.

Bel, G., Fageda, X., \& Warner, M. E. (2010). Is private production of public services cheaper than public production? A meta-regression analysis of solid waste and water services. Journal of Policy Analysis and Management, 29, 553-577.

Bel, G. \& Warner, M. E. (2008). Does privatization of solid waste and water services reduce costs? A review of empirical studies. Resources, Conservation \& Recycling, 52, 1337-1348.

Berechman, J. (1993). Public Transit Economics and Deregulation Policy. Amsterdam, Netherlands: North-Holland.

Boitani, A. \& Cambini, C. (2006). To bid or not to bid, this is the question: The Italian experience for local bus services. European Transport, 33, 63-81.

Boitani, A., Nicolini, M., \& Scarpa, C. (2013). Do competition and ownership matter? Evidence from local public transport in Europe. Applied Economics, 45, 1419-1434.

Brown, T. \& Potoski, M. (2003a). Managing Contract Performance: A Transaction Costs Approach. Journal of Policy Analysis and Management, 20, 275-297.

Brown, T. L. \& Potoski, M. (2003b). Transaction Costs and Institutional Explanations for Government Service Production Decisions. Journal of Public Administration Research and Theory, 13, 441-468.

Brown, T. \& Potoski, M. (2005). Transaction costs and contracting: The practitioner perspective. Public Performance \& Management Review, 28, 326-351.

Brown, T. \& Potoski, M. (2006). Contracting for Management: Assessing Management Capacity under Alternative Service Delivery Arrangements. Journal of Policy Analysis and Management, 25, 323-346. 
Brown, T., Potoski, M., \& Van Slyke, D. (2006). Managing Public Service Contracts: Aligning Values, Institutions, and Markets. Public Administration Review, 66, 323-331.

Brown, T., Potoski, M., \& Van Slyke, D. (2008). Changing Modes of Service Delivery: How Past Choices Structure Future Choices. Environment and Planning C: Government and Policy, 26, 127-143.

Cambini, C., Piacenza, M., \& Vannoni, D. (2007). Restructuring public transit systems: Evidence on cost properties from medium and large-sized companies. Review of Industrial Organization, 31, 183-203.

Christensen, L. R., Jorgenson, D. W., \& Lawrence, J. L. (1973). Transcendental logarithmic production frontiers. The Review of Economics and Statistics, 55, 28-45.

Coelli, T. (2003). A Primer on Efficiency for Utilities and Transport Regulators. Washington, D.C.: World Bank Publications.

Croissant, Y., Roy, W., \& Canton, J. (2013). Reducing urban public transport costs by tendering lots: A panel data estimation. Applied Economics, 45, 3711-3722.

Cruz, N. F., Marques, R. C., Marra, A., \& Pozzi, C. (2014). Local Mixed Companies: The Theory and Practice in an International Perspective. Annals of Public and Cooperative Economics, 85, 1-10.

De Borger, B., Kerstens, K., \& Costa, A (2002). Public transit performance: What does one learn from frontier studies? Transport Reviews, 22, 1-38.

Farsi, M., Filippini, M., \& Kuenzle, M. (2006). Cost efficiency in regional bus companies: An application of alternative stochastic frontier models. Journal of Transport Economics and Policy, 40, 95-118.

Fazioli, R., Filippini, M., \& Prioni, P. (1993). Cost Structure and Efficiency of Local Public Transport: The Case of Emilia Romagna Bus Companies. International Journal of Transport Economics, 3, 305-324.

Filippini, M. \& Prioni, P. (2003). The influence of ownership on the cost of bus service provision in Switzerland-An empirical illustration. Applied Economics, 35, 683-690.

Fraquelli, G., Piacenza, M., \& Abrate, G. (2004). Regulating Public Transit Networks: How do Urban Intercity Diversification Speed up Measures Affect Firms' Cost Performance? Annals of Public and Cooperative Economics, 75, 193-225.

Gagnepain, P. (1998). Structures productives de l'industrie du transport urbain et effets des schémas réglementaires. Economie et Prevision, 135, 95-107.

Gagnepain, P., Ivaldi, M., \& Martimort, D. (2013). The cost of contract renegotiation: Evidence from the local public sector. American Economic Review, 103, 2352-2383. 
Girth, A., Hefetz, A., Johnston, J., \& Warner, M. (2012). Outsourcing Public Service Delivery: Management Responses in Noncompetitive Markets. Public Administration Review, 72, 887-900.

Greene, W. (2005). Reconsidering heterogeneity in panel data estimators of the stochastic frontier model. Journal of Econometrics, 126, 269-303.

Greene, W. (2008). The Econometric Approach to Efficiency Analysis. In H. Fried, K. Lovell \& S. Schmidt (Eds.), The Measurement of Productive Efficiency and Productivity Growth (pp. 93-250). Oxford, UK: Oxford University Press.

Hatry, H. P. (1999). Privatization: The Provision of Public Services by the Private Sector. Jefferson, NC: McFarland \& Company, Inc.

Hefetz, A. \& Warner, M. E. (2012). Contracting or Public Delivery? The Importance of Service, Market and Management Characteristics. Journal of Public Administration Research and Theory, 22, 289-317.

Heinrich, C. J. \& Marschke, G. (2010). Incentives and Their Dynamics in Public Sector Performance Management Systems. Journal of Policy Analysis and Management, 29, 183208.

Hensher, D. A. (2015). Cost Efficiency under Negotiated Performance-Based Contracts and Benchmarking-Are there gains through Competitive Tendering in the absence of an Incumbent Public Monopolist? Journal of Transport Economics and Policy, 49, 133-148.

Hensher, D. A. \& Stanley, J. (2008). Transacting under a performance-based contract: The role of negotiation and competitive tendering. Transportation Research Part A: Policy and Practice, 42, 1143-1151.

Hensher, D. A. \& Wallis, I. (2005). Competitive tendering as a contracting mechanism for subsidising transport: The bus experience. Journal of Transport Economics and Policy, 39, 295-321.

Hill, C., \& Lynn, L. (2004). Governance and public management, an introduction. Journal of Policy Analysis and Management, 23, 3-12.

Hirsch, W. Z. (1995). Contracting Out by Urban Governments: A Review. Urban Affairs Review, 30, 458-72.

Jørgensen, F., Pedersen, P. A., \& Volden, R. (1997). Estimating the inefficiency in the Norwegian bus industry from stochastic cost frontier models. Transportation, 24, 421-533.

Knott, J., \& Payne, A. (2004). The impact of state governance structures on management and performance of public organizations: A study of higher education institutions. Journal of Policy Analysis and Management, 23, 13-30.

Koning, P. \& Heinrich, C. J. (2013). Cream-Skimming, Parking and Other Intended and Unintended Effects of High-Powered, Performance-Based Contracts. Journal of Policy Analysis and Management, 32, 461-483. 
Lamothe, M. \& Lamothe, S. (2012). To Trust or Not to Trust? What Matters in Local Government-Vendor Relationships? Journal of Public Administration Research and Theory, 22, 867-892.

Lamothe, S., Lamothe, M., \& Feiock, R. C. (2008). Examining Local Government Service Delivery Arrangements over Time. Urban Affairs Review, 44, 27-56.

Landau, M. (1969). Redundancy, Rationality, and the Problem of Duplication and Overlap. Public Administration Review, 39, 346-358.

Lee, R. W. \& Rivasplata C. R. (2001). Metropolitan Transportation Planning in the 1990s: Comparisons and Contracts in New Zealand, Chile and California. Transport Policy, 8, 4761.

Leland, S. \& Smirnova, O. (2009). Reassessing Privatization Strategies 25 Years Later: Revisiting Perry and Babitsky's Comparative Performance Study of Urban Bus Transit Services. Public Administration Review, 69, 855-867.

Levaggi, R. (1994). Parametric and non-parametric approach to efficiency: The case of urban transport in Italy. Studi Economici, 49, 67-88.

Levin, J. \& Tadelis, S. (2010). Contracting for government services: Theory and evidence from U.S. cities. Journal of Industrial Economics, 58, 507-541.

Mackie, P., Preston, J., \& Nash, C. (1995). Bus deregulation: Ten years on. Transport Reviews, 15, 229-251.

Matas, A. \& Raymond, J. L. (1998). Technical characteristics and efficiency of urban bus companies: The case of Spain. Transportation, 25, 243-263.

Mathisen, T. A. \& Solvoll, G. (2008). Competitive tendering and structural changes: An example from the bus industry. Transport Policy, 15, 1-11.

Meier, K., O’Toole, L., Jr., \& Nicholson-Crotty, S. (2004). Multilevel governance and organizational performance: Investigating the political bureaucratic labyrinth. Journal of Policy Analysis and Management, 23, 31-48.

Miranda, R. \& Lerner, A. (1995). Bureaucracy, Organizational Redundancy, and the Privatization of Public Services. Public Administration Review, 55, 193-200.

Mouwen, A. \& Rietveld, P. (2013). Does competitive tendering improve customer satisfaction with public transport? A case study for the Netherlands. Transportation Research Part A: Policy and Practice, 51, 29-45.

Obeng, K. (1985) Bus transit cost, productivity and factor substitution. Journal of Transport Economics and Policy, 19, 183-203.

Ottoz, E., Fornengo, G., \& Di Giacomo, M. (2009). The impact of ownership on the cost of bus service provision: An example from Italy. Applied Economics, 41, 337-350. 
Sappington, D. \& Stiglitz, J. E. (1987). Privatization, information and incentives, Journal of Policy Analysis and Management, 6, 567-957.

Savage, I. (1993). Deregulation and privatization of Britain's local bus industry. Journal of Regulatory Economics, 5, 143-158.

Viton, P. (1981). A Translog Cost Function for Urban Bus Transit. Journal of Industrial Economics, 29, 287-304.

Warner, M. E. \& Bel, G. (2008). Competition or monopoly? Comparing privatization of local public services in the U.S. and Spain. Public Administration, 86, 723-735.

Warner, M. E. \& Hefetz, A. (2002). The Uneven Distribution of Market Solutions for Public Goods. Journal of Urban Affairs, 24, 445-459.

Warner, M. E. \& Hefetz, A. (2003). Rural-Urban Differences in Privatization: Limits to the Competitive State. Environment and Planning C: Government and Policy, 21, 703-718.

Warner, M. E. \& Hefetz, A. (2008). Managing Markets for Public Service: The Role of Mixed Public/Private Delivery of City Services. Public Administration Review, 68, 150-161.

White, P. R. (1997). What Conclusions Can Be Drawn about Bus Deregulation in Britain? Transport Reviews, 17, 1-16.

Williamson, O. (1991). Comparative Economic Organization: The Analysis of Discrete Structural Alternatives. Administration Science Quarterly, 36, 269-296.

Williamson, O. (1999). A Transaction Cost Economics Perspective. Journal of Law, Economics and Organization, 15, 306-342.

Yvrande-Billon, A. (2006). The attribution process of delegation contracts in the French urban public transport sector: Why competitive tendering is a myth. Annals of Public and Cooperative Economics, 77, 453-478. 
Table 1. Model variables and their definitions.

\begin{tabular}{|c|c|c|}
\hline $\begin{array}{l}\text { Grouping } \\
\text { variables }\end{array}$ & Variable & Definition \\
\hline $\begin{array}{l}\text { Dependent } \\
\text { variable }\end{array}$ & $\begin{array}{l}\text { Variable Costs } \\
\text { (TVC) }\end{array}$ & $\begin{array}{l}\text { This includes labor, fuel, maintenance and other indirect costs } \\
\text { (such as administration and coordination costs at the line level, } \\
\text { both for public and private firms). We exclude the bus fleet costs. } \\
\text { We evaluate these costs in two different scenarios, depending on } \\
\text { whether we include transaction costs or not. The transaction cost } \\
\text { is the regulator's total budget, and we distribute it equally } \\
\text { between each private line. }^{\text {a }}\end{array}$ \\
\hline \multicolumn{2}{|l|}{ Output (Y) } & $\begin{array}{l}\text { We use vehicle } \cdot \text { kilometers, a supply-related measure. Seat- } \\
\text { kilometers would have been another suitable measure, but we } \\
\text { have no data here for private companies. The output is expected } \\
\text { to have a positive sign. }\end{array}$ \\
\hline \multirow[b]{2}{*}{ Price of inputs } & $\begin{array}{l}\text { Price of labor } \\
\text { (PL) }\end{array}$ & $\begin{array}{l}\text { The ratio of total salary expenses to the total number of hours } \\
\text { worked. }\end{array}$ \\
\hline & $\begin{array}{l}\text { Price of material } \\
(\mathrm{PM})\end{array}$ & $\begin{array}{l}\text { This is obtained by dividing fuel and maintenance material costs } \\
\text { by net kilometers covered. This variable divides the dependent } \\
\text { variable and the price of labor in the equation. }\end{array}$ \\
\hline \multicolumn{2}{|c|}{ Capital (quasi-fixed, K) } & $\begin{array}{l}\text { Capital is represented by the number of buses. It is considered a } \\
\text { quasi-fixed factor because buses are owned by the regulator. We } \\
\text { expected a negative sign. }\end{array}$ \\
\hline \multirow{2}{*}{$\begin{array}{l}\text { Network } \\
\text { characteristics }\end{array}$} & Line length $(\mathrm{N})$ & $\begin{array}{l}\text { This variable serves as a proxy for exogenous characteristics such } \\
\text { as public service obligations. Line length is the round trip } \\
\text { distance divided by two. Expectations regarding the effects of } \\
\text { line length on costs are ambiguous. }\end{array}$ \\
\hline & $\begin{array}{l}\text { Average speed } \\
\text { (SP) }\end{array}$ & $\begin{array}{l}\text { If a trip is covered in a shorter time, fewer vehicles and less labor } \\
\text { force are required. Therefore, costs are expected to decrease with } \\
\text { increasing network speed. Average speed is the number of } \\
\text { kilometers divided by service hours. }\end{array}$ \\
\hline $\begin{array}{l}\text { Competition and } \\
\text { ownership } \\
\text { variables }\end{array}$ & $\begin{array}{l}\text { Tender year } \\
\text { (TEND) }\end{array}$ & $\begin{array}{l}\text { This dummy variable takes a value of } 1 \text { for the year immediately } \\
\text { following a tender process (that is, the year in which the new } \\
\text { concession terms are applied). New contracts come into force on } \\
\text { January } 1 \text {, even though the contest has been celebrated in the } \\
\text { previous year. If tenders were cost-minimizing artifacts, costs } \\
\text { should decrease following a tender process. }\end{array}$ \\
\hline
\end{tabular}




\begin{tabular}{|c|c|c|}
\hline & Private (PRIV) & $\begin{array}{l}\text { This binary variable takes a value of } 1 \text { if the line is operated by a } \\
\text { private company and } 0 \text { if it is operated by the public company } \\
\text { TMB. Most empirical evidence for bus services indicates that } \\
\text { private companies incur lower costs, but this evidence is not } \\
\text { systematic across other local service sectors, such as solid waste } \\
\text { and water. }\end{array}$ \\
\hline & $\begin{array}{l}\text { Concession } \\
\text { dummies (TUS, } \\
\text { ROS, SOL) }\end{array}$ & $\begin{array}{l}\text { A dummy that clusters the same concession's bus lines up to a } \\
\text { total of four. The private ones are TUS (Tusgsal), ROS } \\
\text { (Rosanbus) and SOL (Soler i Sauret) }\end{array}$ \\
\hline \multirow{3}{*}{ Control variables } & $\begin{array}{l}\text { Barcelona } \\
\text { (BARC) }\end{array}$ & $\begin{array}{l}\text { This dummy variable takes a value of } 1 \text { if the whole bus line is } \\
\text { within the municipality of Barcelona, and } 0 \text { otherwise. In this } \\
\text { way we control for the effect of the city of Barcelona on the cost } \\
\text { function. }\end{array}$ \\
\hline & Metro (METR) & $\begin{array}{l}\text { This dummy variable takes a value of } 1 \text { if the bus line is affected } \\
\text { by the new metropolitan subway lines opened in } 2010 \text {, and } 0 \\
\text { otherwise. }\end{array}$ \\
\hline & $\begin{array}{l}\text { Municipality } \\
\text { (MUN) }\end{array}$ & $\begin{array}{l}\text { This dummy takes a value of } 1 \text { if the bus route is within the same } \\
\text { municipality (but outside Barcelona), and } 0 \text { otherwise. }\end{array}$ \\
\hline
\end{tabular}

${ }^{\text {a }}$ Recall that EMT's costs are not allocated to TMB lines, because it does not regulate TMB and does not undertake any other functional activity with respect to TMB. Both TMB and EMT are subject to political supervision by representatives of local governments in the Metropolitan Area of Barcelona. 
Table 2. Mean (standard error) based on 405 bus line observations (2002 to 2012).

\begin{tabular}{|c|c|c|c|c|}
\hline & \multicolumn{4}{|c|}{ Concessionaires } \\
\hline & TMB & $\begin{array}{l}\text { Barcelonès Nord } \\
\text { (Tusgsal) }\end{array}$ & $\begin{array}{c}\text { Hospitalet de } \\
\text { Llobregat (Rosanbus) }\end{array}$ & $\begin{array}{l}\text { West Barcelona } \\
\text { (Soler Sauret) }\end{array}$ \\
\hline Average speed $(\mathrm{km} / \mathrm{h})$ & $12.91(0.147)$ & $10.72(0.203)$ & $12.604(0.307)$ & $12.58(0.408)$ \\
\hline Length line (km) & $10.454(0.223)$ & $8.576(0.496)$ & $11.396(0.82)$ & $10.308(0.364)$ \\
\hline Net km (km) & $430,924(13337.5)$ & $293,336(20,762.6)$ & $306,643(19,145.1)$ & $123,505(10,751.1)$ \\
\hline Vehicles & $10.96(0.343)$ & $5.48(0.399)$ & $6.155(0.392)$ & $2.63(0.176)$ \\
\hline Bus age (years) & $6.49(0.04)$ & $4.47(0.05)$ & $5.02(0.09)$ & $6.23(0.29)$ \\
\hline Employees & $32.0(1.05)$ & $27.02(1.46)$ & $16.59(1.28)$ & $6.25(0.5)$ \\
\hline Passengers & $1,569,978(69639)$ & $883,722(61,527)$ & $1,129,646(121,391)$ & $176,540(20,299)$ \\
\hline Cost per net km & $4.10(0.059)$ & $5.13(0.116)$ & $3.85(0.131)$ & $3.33(0.183)$ \\
\hline Revenues per net km & $1.62(0.04)$ & $1.47(0.06)$ & $1.55(0.13)$ & $0.59(0.04)$ \\
\hline Total costs $(€)$ & $1,784,709(62,653)$ & $1,391,206(78,470)$ & $1,073,187(76,330)$ & $379,854.4(44,492)$ \\
\hline Transaction costs $(€)$ & 0 & $52,217.17(971.9)$ & $51,435.91(1389.95)$ & $51,172.17(2556.0)$ \\
\hline $\begin{array}{l}\text { Analyzed lines (yearly } \\
\text { average) }\end{array}$ & 21 & 9.4 & 5.4 & 1.6 \\
\hline
\end{tabular}


Table 3. Cost frontier estimation with time varying effects-Battese and Coelli (1992) model (standard errors in parentheses).

\begin{tabular}{|c|c|c|c|c|}
\hline & \multicolumn{2}{|c|}{ Dep. variable without transaction costs } & \multicolumn{2}{|c|}{ Dep. variable with transaction costs } \\
\hline & (1) & (2) & (3) & (4) \\
\hline \multirow{2}{*}{$\beta_{\mathrm{Y}}$} & $1.290 * * *$ & $1.295 * * *$ & $0.368 * * *$ & $0.311 * * *$ \\
\hline & $(0.110)$ & $(0.104)$ & $(0.110)$ & $(0.106)$ \\
\hline \multirow{2}{*}{$\beta_{\mathrm{N}}$} & -0.023 & -0.036 & $1.537 * * *$ & $1.557 * * *$ \\
\hline & $(0.059)$ & $(0.056)$ & $(0.339)$ & $(0.581)$ \\
\hline \multirow{2}{*}{$\beta_{\mathrm{SP}}$} & -0.144 & -0.141 & $-1.644 * *$ & $-1.657 *$ \\
\hline & $(0.128)$ & $(0.121)$ & $(0.932)$ & $(0.965)$ \\
\hline \multirow{2}{*}{$\beta_{\mathrm{PL}}$} & $0.544 * * *$ & $0.563 * * *$ & $0.803 * * *$ & $0.843 * * *$ \\
\hline & $(0.058)$ & $(0.055)$ & $(0.196)$ & $(0.175)$ \\
\hline \multirow{2}{*}{$\beta_{\mathrm{K}}$} & $-1.582 * * *$ & $-1.579 * * *$ & $-0.448 * * *$ & $-0.334 * * *$ \\
\hline & $(0.224)$ & $(0.212)$ & $(0.115)$ & $(0.092)$ \\
\hline \multirow{2}{*}{$\beta_{\text {Time }}$} & $-1 \mathrm{E}-04 * *$ & $-1 \mathrm{E}-04 * *$ & $-0.002 * *$ & $-0.015^{* * *}$ \\
\hline & (6E-05) & (5E-05) & $(0.001)$ & (4E-04) \\
\hline \multirow{2}{*}{ Tender year } & 0.000 & 0.000 & $-0.013 *$ & $-0.013^{*}$ \\
\hline & $(0.001)$ & $(0.001)$ & $(0.007)$ & $(0.007)$ \\
\hline \multirow{2}{*}{ Private } & $0.006 * * *$ & & $0.103 * * *$ & \\
\hline & $(0.001)$ & & $(0.009)$ & \\
\hline \multirow{2}{*}{ Tusgsal } & & $0.007 * * *$ & & $0.104 * * *$ \\
\hline & & $(0.001)$ & & $(0.010)$ \\
\hline \multirow{2}{*}{ Rosanbus } & & $0.005^{* * *}$ & & $0.103 * * *$ \\
\hline & & $(0.001)$ & & $(0.011)$ \\
\hline \multirow{2}{*}{ Soler Sauret } & & $0.005 * * *$ & & $0.096 * * *$ \\
\hline & & $(0.001)$ & & $(0.014)$ \\
\hline \multirow{2}{*}{$\beta_{\mathrm{BCN}}$} & 0.000 & 0.000 & 0.005 & 0.005 \\
\hline & $(0.001)$ & $(0.001)$ & $(0.005)$ & $(0.005)$ \\
\hline \multirow{2}{*}{$\beta_{\text {MUN }}$} & $-0.001 * *$ & 0.000 & -0.004 & -0.003 \\
\hline & (4E-04) & (4E-04) & $(0.005)$ & $(0.005)$ \\
\hline \multirow{2}{*}{$\beta_{\mathrm{MET}}$} & 0.000 & 0.000 & 0.000 & 0.000 \\
\hline & $(0.001)$ & $(0.001)$ & $(0.005)$ & $(0.006)$ \\
\hline \multirow{2}{*}{$\eta$} & 0.367 & 0.328 & -0.014 & -0.025 \\
\hline & $(0.287)$ & $(0.410)$ & $(0.135)$ & $(0.164)$ \\
\hline$\lambda=\sigma_{\mathrm{u}} / \sigma_{\mathrm{v}}$ & $1.119 * * *$ & 0.033 & $1.577 * * *$ & $1.2156^{* * *}$ \\
\hline Log likelihood & 1728.33 & 1734.66 & 944.35 & 944.33 \\
\hline Observations & 378 & 378 & 378 & 378 \\
\hline
\end{tabular}

Significance levels: $* 10$ percent; $* * 5$ percent; $* * * 1$ percent 
Table 4. Cost frontier estimation-True Random Effects model (standard errors in parentheses).

\begin{tabular}{|c|c|c|c|c|}
\hline & \multicolumn{2}{|c|}{ Dep. variable without transaction costs } & \multicolumn{2}{|c|}{ Dep. variable with transaction costs } \\
\hline & (5) & (6) & (7) & $(8)$ \\
\hline \multirow{2}{*}{$\beta_{\mathrm{Y}}$} & $0.813 * * *$ & $0.959 * * *$ & -0.060 & -0.202 \\
\hline & $(0.1574)$ & $(0.1262)$ & $(0.8515)$ & $(0.8701)$ \\
\hline \multirow{2}{*}{$\beta_{\mathrm{N}}$} & $-0.997 * * *$ & $-0.343 * * *$ & $1.128 * *$ & $0.869 *$ \\
\hline & $(0.1059)$ & $(0.0595)$ & $(0.5109)$ & $(0.5241)$ \\
\hline \multirow{2}{*}{$\beta_{\mathrm{SP}}$} & $1.198 * * *$ & 0.087 & -1.383 & -1.122 \\
\hline & $(0.2363)$ & $(0.1388)$ & $(0.8860)$ & $(0.9592)$ \\
\hline \multirow{2}{*}{$\beta_{\mathrm{PL}}$} & 1.111 & $0.824 * * *$ & $1.114 * *$ & 1.394 \\
\hline & $(0.1283)$ & $(0.0782)$ & $(0.4625)$ & $(0.4277)$ \\
\hline \multirow{2}{*}{$\beta_{\mathrm{K}}$} & -0.463 & $-0.837 * * *$ & 0.583 & 1.017 \\
\hline & $(0.3135)$ & $(0.2600)$ & $(1.7640)$ & $(1.8111)$ \\
\hline \multirow{2}{*}{$\beta_{\text {Time }}$} & 0.000 & 0.000 & $-0.002 * * *$ & $-0.002 * * *$ \\
\hline & $(0.0002)$ & $(0.4177)$ & $(0.0006)$ & $(0.0006)$ \\
\hline \multirow{2}{*}{ Tender year } & $-0.003 *$ & -0.001 & $-0.015^{*}$ & $-0.015^{*}$ \\
\hline & $(0.0017)$ & $(0.0012)$ & $(0.0088)$ & $(0.0086)$ \\
\hline \multirow{2}{*}{ Private } & 0.004 & & $0.095 * * *$ & \\
\hline & $(0.0034)$ & & $(0.0114)$ & \\
\hline \multirow{2}{*}{ Tusgsal } & & $0.008 * * *$ & & $0.104 * * *$ \\
\hline & & $(0.0024)$ & & $(0.0140)$ \\
\hline \multirow{2}{*}{ Rosanbus } & & $0.006^{* * *} *$ & & $0.094 * * *$ \\
\hline & & $(0.0024)$ & & $(0.0133)$ \\
\hline \multirow{2}{*}{ Soler Sauret } & & $0.005 * * *$ & & $0.089 * * *$ \\
\hline & & $(0.0026)$ & & $(0.0121)$ \\
\hline \multirow{2}{*}{$\beta_{\mathrm{BCN}}$} & -0.001 & 0.0002 & 0.003 & 0.004 \\
\hline & (0.0017) & $(0.0014)$ & (0.0069) & $(0.0068)$ \\
\hline \multirow{2}{*}{$\beta_{\mathrm{MUN}}$} & -0.001 & -0.001 & -0.001 & -0.003 \\
\hline & (0.0009) & (0.0008) & $(0.0043)$ & $(0.0043)$ \\
\hline \multirow{2}{*}{$\beta_{\mathrm{MET}}$} & 0.001 & -0.001 & 0.003 & 0.001 \\
\hline & $(0.0019)$ & $(0.0013)$ & $(0.0083)$ & $(0.0083)$ \\
\hline$\lambda=\sigma_{\mathrm{u}} / \sigma_{\mathrm{v}}$ & $1.288 * * *$ & 0.163 & $1.996 * * *$ & $2.879 * * *$ \\
\hline $\begin{array}{c}\text { Log } \\
\text { likelihood }\end{array}$ & 1532.50 & 1765.69 & 951.24 & 953.22 \\
\hline Observations & 405 & 405 & 405 & 405 \\
\hline
\end{tabular}

Significance levels: * 10 percent; $* * 5$ percent; $* * * 1$ percent 
Table 5. Estimated cost inefficiency scores by specification.

\begin{tabular}{|c|c|c|c|c|c|c|c|c|}
\hline \multicolumn{9}{|c|}{ Inefficiency scores by specification } \\
\hline & & \multicolumn{5}{|c|}{ Statistics } & \multicolumn{2}{|c|}{ Kruskal-Wallis test } \\
\hline $\begin{array}{l}\text { Stochastic } \\
\text { frontier } \\
\text { approach }\end{array}$ & $\begin{array}{c}\text { Specificatio } \\
\mathrm{n}\end{array}$ & Ownership & Mean & $\begin{array}{l}\text { Standard } \\
\text { deviation }\end{array}$ & Minimum & Maximum & Chi-sq & t-statistic \\
\hline \multirow{8}{*}{$\begin{array}{c}\text { Battese and } \\
\text { Coelli (1992) }\end{array}$} & \multirow{2}{*}{1} & Public & $2 \cdot 10^{-5}$ & $2 \cdot 10^{-5}$ & $2 \cdot 10^{-6}$ & $1 \cdot 10^{-4}$ & \multirow{2}{*}{9.452} & \multirow{2}{*}{$0.0021 * * *$} \\
\hline & & Private & $1 \cdot 10^{-5}$ & $1 \cdot 10^{-5}$ & $2 \cdot 10^{-6}$ & $7 \cdot 10^{-5}$ & & \\
\hline & \multirow{2}{*}{2} & Public & $2 \cdot 10^{-5}$ & $2 \cdot 10^{-5}$ & $2 \cdot 10^{-6}$ & $6 \cdot 10^{-5}$ & \multirow{2}{*}{9.446} & \multirow{2}{*}{$0.0021 * * *$} \\
\hline & & Private & $1 \cdot 10^{-5}$ & $1 \cdot 10^{-5}$ & $2 \cdot 10^{-6}$ & $4 \cdot 10^{-5}$ & & \\
\hline & \multirow{2}{*}{3} & Public & 0.006 & 0.0041 & 0.0012 & 0.0195 & \multirow{2}{*}{5.714} & \multirow{2}{*}{$0.0168 * *$} \\
\hline & & Private & 0.005 & 0.0037 & 0.0027 & 0.0189 & & \\
\hline & \multirow{2}{*}{4} & Public & 0.007 & 0.0043 & 0.0012 & 0.0205 & \multirow{2}{*}{7.996} & \multirow{2}{*}{$0.0047 * * *$} \\
\hline & & Private & 0.006 & 0.0035 & 0.0026 & 0.0176 & & \\
\hline \multirow{8}{*}{$\begin{array}{l}\text { True Random } \\
\text { Effects } \\
\text { (Greene, 2005) }\end{array}$} & \multirow{2}{*}{5} & Public & 0.003 & 0.0009 & 0.0012 & 0.0120 & \multirow{2}{*}{20.365} & \multirow{2}{*}{$0.0001 * * *$} \\
\hline & & Private & 0.004 & 0.0023 & 0.0005 & 0.0173 & & \\
\hline & \multirow{2}{*}{6} & Public & $3 \cdot 10^{-4}$ & $1 \cdot 10^{-5}$ & $3 \cdot 10^{-4}$ & 0.0004 & \multirow{2}{*}{8.791} & \multirow{2}{*}{$0.003 * * *$} \\
\hline & & Private & $3 \cdot 10^{-4}$ & $2 \cdot 10^{-5}$ & $1 \cdot 10^{-4}$ & 0.0004 & & \\
\hline & \multirow{2}{*}{7} & Public & 0.017 & 0.0064 & 0.0046 & 0.0557 & \multirow{2}{*}{0.896} & \multirow{2}{*}{0.344} \\
\hline & & Private & 0.023 & 0.0203 & 0.0021 & 0.1367 & & \\
\hline & \multirow{2}{*}{8} & Public & 0.018 & 0.0079 & 0.0039 & 0.0641 & \multirow{2}{*}{2.008} & \multirow{2}{*}{0.156} \\
\hline & & Private & 0.027 & 0.0261 & 0.0019 & 0.1661 & & \\
\hline
\end{tabular}

Significance levels: * 10 percent; ** 5 percent; $* * * 1$ percent 
Table 6. Robustness test. Cost frontier estimation Battese and Coelli and True Random Effects (standard errors in parentheses).

\begin{tabular}{|c|c|c|c|c|}
\hline & \multicolumn{4}{|c|}{ Dependent variable with transaction costs by passengers } \\
\hline & \multicolumn{2}{|c|}{ Battese and Coelli } & \multicolumn{2}{|c|}{ True Random Effects } \\
\hline & (9) & (10) & $(11)$ & (12) \\
\hline$\beta_{\mathrm{Y}}$ & $\begin{array}{c}0.583 * \\
(0.3372)\end{array}$ & $\begin{array}{c}-0.063 \\
(0.5422)\end{array}$ & $\begin{array}{c}1.278 \\
(0.9359)\end{array}$ & $\begin{array}{c}0.323 \\
(0.6878)\end{array}$ \\
\hline$\beta_{\mathrm{N}}$ & $\begin{array}{l}-0.368^{*} \\
(0.2176)\end{array}$ & $\begin{array}{c}-0.001 \\
(0.2918)\end{array}$ & $\begin{array}{c}0.035 \\
(0.3674)\end{array}$ & $\begin{array}{c}-0.042 \\
(0.2635)\end{array}$ \\
\hline$\beta_{\mathrm{SP}}$ & $\begin{array}{c}-1.103 * * * \\
(0.3828)\end{array}$ & $\begin{array}{l}-1.043 * \\
(0.6280)\end{array}$ & $\begin{array}{c}0.221 \\
(1.0246)\end{array}$ & $\begin{array}{c}-0.457 \\
(0.7727)\end{array}$ \\
\hline$\beta_{\mathrm{PL}}$ & $\begin{array}{c}0.598 * * * \\
(0.1751)\end{array}$ & $\begin{array}{c}0.472 * \\
(0.2863)\end{array}$ & $\begin{array}{c}0.315 \\
(0.5325)\end{array}$ & $\begin{array}{c}0.330 \\
(0.3817)\end{array}$ \\
\hline$\beta_{\mathrm{K}}$ & $\begin{array}{c}0.156 \\
(0.6766)\end{array}$ & $\begin{array}{c}1.070 \\
(1.1030)\end{array}$ & $\begin{array}{c}-1.605 \\
(1.8096)\end{array}$ & $\begin{array}{c}0.278 \\
(1.3321)\end{array}$ \\
\hline$\beta_{\text {Time }}$ & $\begin{array}{c}-5.82 \mathrm{e}-05 \\
(0.0002)\end{array}$ & $\begin{array}{c}-0.001 * * * \\
(0.0003)\end{array}$ & $\begin{array}{c}-0.001 \\
(0.0006)\end{array}$ & $\begin{array}{c}-0.001 * * * \\
(0.0004)\end{array}$ \\
\hline Tender year & $\begin{array}{c}-0.011 * * * \\
(0.0024)\end{array}$ & $\begin{array}{c}-0.014 * * * \\
(0.0042)\end{array}$ & $\begin{array}{l}-0.014 * * \\
(0.0065)\end{array}$ & $\begin{array}{c}-0.013 * * * \\
(0.0047)\end{array}$ \\
\hline Private & $\begin{array}{l}0.048 * * * \\
(0.0050)\end{array}$ & & $\begin{array}{l}0.060 \text { *** } \\
(0.01307)\end{array}$ & \\
\hline Tusgsal & & $\begin{array}{c}0.061^{* * *} \\
(0.006)\end{array}$ & & $\begin{array}{c}0.057 * * * \\
(0.0096)\end{array}$ \\
\hline Rosanbus & & $\begin{array}{c}0.094 * * * \\
(0.0057)\end{array}$ & & $\begin{array}{c}0.084 * * * \\
(0.0091)\end{array}$ \\
\hline Soler Sauret & & $\begin{array}{c}0.061 * * * \\
(0.0067)\end{array}$ & & $\begin{array}{c}0.057 * * * \\
(0.0104)\end{array}$ \\
\hline$\beta_{\mathrm{BCN}}$ & $\begin{array}{c}0.004 \\
(0.0026)\end{array}$ & $\begin{array}{l}0.009 * * * \\
(0.0024)\end{array}$ & $\begin{array}{c}0.005 \\
(0.0056)\end{array}$ & $\begin{array}{c}0.0073 * * \\
(0.0037)\end{array}$ \\
\hline$\beta_{\mathrm{MUN}}$ & $\begin{array}{l}-0.007 * * \\
(0.0033)\end{array}$ & $\begin{array}{c}-0.016^{* * *} \\
(0.0019)\end{array}$ & $\begin{array}{c}-0.007 * * \\
(0.0105)\end{array}$ & $\begin{array}{c}-0.013 * * * \\
(0.0021)\end{array}$ \\
\hline$\beta_{\mathrm{MET}}$ & $\begin{array}{c}-0.002 \\
(0.0019)\end{array}$ & $\begin{array}{c}-0.004 \\
(0.0034)\end{array}$ & $\begin{array}{c}-0.007 \\
(0.0045)\end{array}$ & $\begin{array}{c}-0.003 \\
(0.0039)\end{array}$ \\
\hline$\eta$ & $\begin{array}{c}0.063 * * * \\
(0.0069)\end{array}$ & $\begin{array}{l}0.498 * * * \\
(0.1156)\end{array}$ & - & - \\
\hline$\lambda=\sigma_{\mathrm{u}} / \sigma_{\mathrm{v}}$ & 79.59 & 0.05 & $3.828 * * *$ & $2.015^{* * *}$ \\
\hline Log likelihood & 1275.71 & 1127.25 & 1101.58 & 1142.51 \\
\hline Observations & 378 & 378 & 405 & 405 \\
\hline
\end{tabular}

Note: The dependent variable includes transaction costs allocated by passengers in the line. Significance levels: * 10 percent; ** 5 percent; *** 1 percent 
Table 7. Estimated cost inefficiency scores by specification.

\begin{tabular}{|c|c|c|c|c|c|c|c|c|}
\hline \multicolumn{9}{|c|}{ Inefficiency scores by specification } \\
\hline & & \multicolumn{5}{|c|}{ Statistics } & \multicolumn{2}{|c|}{ Kruskal-Wallis test } \\
\hline $\begin{array}{l}\text { Stochastic } \\
\text { frontier } \\
\text { approach }\end{array}$ & Specification & Ownership & Mean & $\begin{array}{l}\text { Standard } \\
\text { deviation }\end{array}$ & Minimum & Maximum & Chi-sq & t-statistic \\
\hline \multirow{4}{*}{$\begin{array}{c}\text { Battese and } \\
\text { Coelli } \\
\text { (1992) }\end{array}$} & \multirow{2}{*}{9} & Public & 0.004 & 0.0021 & 0.0012 & 0.0096 & \multirow{2}{*}{172.78} & \multirow{2}{*}{$0.0001 * * *$} \\
\hline & & Private & 0.034 & 0.0288 & 0.0019 & 0.1444 & & \\
\hline & \multirow{2}{*}{10} & Public & 0.0001 & 0.0006 & $1 \cdot 10^{-5}$ & 0.0029 & \multirow{2}{*}{5.118} & \multirow{2}{*}{$0.024 * *$} \\
\hline & & Private & 0.0002 & 0.0006 & $2 \cdot 10^{-5}$ & 0.0058 & & \\
\hline \multirow{4}{*}{$\begin{array}{c}\text { True } \\
\text { Random } \\
\text { Effects }\end{array}$} & \multirow{2}{*}{11} & Public & 0.011 & 0.0032 & 0.0039 & 0.0221 & \multirow{2}{*}{13.001} & \multirow{2}{*}{$0.0003 * * *$} \\
\hline & & Private & 0.020 & 0.0212 & 0.0009 & 0.1040 & & \\
\hline & \multirow{2}{*}{12} & Public & 0.010 & 0.0027 & 0.0047 & 0.0221 & \multirow{2}{*}{2.070} & \multirow{2}{*}{0.1502} \\
\hline & & Private & 0.014 & 0.0122 & 0.0011 & 0.0634 & & \\
\hline
\end{tabular}

Significance levels: * 10 percent; ** 5 percent; *** 1 percent 
Table 8. Robustness test. Battese and Coelli and True Random Effects (standard errors in parentheses).

\begin{tabular}{|c|c|c|c|c|}
\hline & \multicolumn{4}{|c|}{ Dependent variable with transaction costs by passengers } \\
\hline & \multicolumn{2}{|c|}{ Battese and Coelli } & \multicolumn{2}{|c|}{ True Random Effects } \\
\hline & (13) & (14) & $(15)$ & $(16)$ \\
\hline & $0.700 * *$ & 0.045 & 1.404 & 0.438 \\
\hline$P_{Y}$ & $(0.3343)$ & $(0.5403)$ & $(0.9582)$ & $(0.7086)$ \\
\hline & -0.289 & 0.010 & 0.174 & -0.011 \\
\hline$P_{N}$ & $(0.2158)$ & $(0.2912)$ & $(0.4101)$ & $(0.2751)$ \\
\hline & $-1.094 * * *$ & -1.025 & 0.135 & -0.451 \\
\hline $\mathrm{P}_{\mathrm{SP}}$ & $(0.3819)$ & $(0.6272)$ & (1.0935) & $(0.7718)$ \\
\hline & $0.525 * * *$ & 0.419 & 0.226 & 0.275 \\
\hline $\mathrm{P}_{\mathrm{PL}}$ & $(0.1750)$ & (0.2859) & $(0.5604)$ & (0.3937) \\
\hline & -0.093 & 0.861 & -1.865 & 0.048 \\
\hline$\beta_{\mathrm{K}}$ & $(0.6699)$ & (1.0983) & $(1.8565)$ & (1.3684) \\
\hline & $8.57 \mathrm{e}-06$ & $-0.001 * * *$ & $-0.001 * * *$ & $-0.001 * * *$ \\
\hline$\rho_{\text {Time }}$ & $(0.0002)$ & $(0.0003)$ & $(0.0005)$ & $(0.0004)$ \\
\hline Tender year & $-0.011 * * *$ & $-0.014 * * *$ & $-0.014 * * *$ & $-0.012 * * *$ \\
\hline remuer yeal & $(0.0022)$ & $(0.0039)$ & $(0.0056)$ & $(0.0045$ \\
\hline Private & $0.0510 * * *$ & & $0.063 * * *$ & \\
\hline Private & $(0.0050)$ & & $(0.0134)$ & \\
\hline Tusacal & & $0.061 * * *$ & & $0.058 * * *$ \\
\hline tusgar & & $(0.0060)$ & & $(0.0097)$ \\
\hline Pocanbus & & $0.094 * * *$ & & $0.085^{* * *}$ \\
\hline Kusallous & & $(0.0057)$ & & $(0.009)$ \\
\hline Solor Couret & & $0.067 * * *$ & & $0.063 * * *$ \\
\hline soler sauret & & $(0.0071)$ & & $(0.0107)$ \\
\hline$\beta_{\text {and }}$ & $0.005^{*}$ & $0.009 * * *$ & 0.005 & $0.007 * * *$ \\
\hline$P_{\mathrm{BCN}}$ & $(0.0026)$ & $(0.0024)$ & $(0.0057)$ & $(0.0037)$ \\
\hline & $-0.008 * *$ & $-0.016^{* * *}$ & $-0.007 * *$ & $-0.013 * * *$ \\
\hline$\beta_{\text {MUN }}$ & (0.0034) & (0.0019) & (0.0027) & $(0.0022)$ \\
\hline & -0.002 & -0.005 & -0.007 & -0.004 \\
\hline$\rho_{\text {MET }}$ & $(0.0018)$ & $(0.0034)$ & $(0.004)$ & $(0.0038)$ \\
\hline $\mathrm{H}$ & $\begin{array}{c}0.064 * * * \\
(0.0071)\end{array}$ & $\begin{array}{c}0.496 * * * \\
(0.1261)\end{array}$ & & - \\
\hline$\lambda=\sigma_{\mathrm{u}} / \sigma_{\mathrm{v}}$ & $3.971 * * *$ & 0.05 & $3.624 * * *$ & $1.988 * * *$ \\
\hline $\begin{array}{c}\text { Log } \\
\text { likelihood }\end{array}$ & 1278.75 & 1127.47 & 1105.07 & 1142.82 \\
\hline Observations & 378 & 378 & 405 & 405 \\
\hline
\end{tabular}

Note: The dependent variable includes transaction costs allocated by passengers per line, and dummy equals 1 for all years after the tender. Significance levels: *10 percent; **5 percent; ***1 percent 


\section{APPENDIX}

Table A1. Bus concessions in the Barcelona Metropolitan Area.

\begin{tabular}{|c|c|c|c|c|c|}
\hline & Concession area & Winner (Group) & $\begin{array}{c}\text { Tender } \\
\text { date }\end{array}$ & $\begin{array}{c}\text { Number of } \\
\text { bidders }\end{array}$ & $\begin{array}{c}\text { Winner lowest } \\
\text { price? }\end{array}$ \\
\hline \multirow{8}{*}{$\begin{array}{l}\text { Competitive } \\
\text { tendering }\end{array}$} & \multirow{2}{*}{ Barcelonès Nord } & Tusgsal & 1998 & 4 & No \\
\hline & & Tusgsal & 2010 & 2 & No \\
\hline & \multirow{2}{*}{$\begin{array}{c}\text { Barcelonès Nord } \\
\text { (Night) }\end{array}$} & Tusgsal & 1998 & 4 & No \\
\hline & & Tusgsal & 2006 & 3 & No \\
\hline & \multirow{2}{*}{ Hospitalet de Llobregat } & $\begin{array}{l}\text { Rosanbus } \\
\text { (Baixbus) }\end{array}$ & 2001 & 5 & No \\
\hline & & $\begin{array}{l}\text { Rosanbus } \\
\text { (Baixbus) }\end{array}$ & 2011 & 5 & No \\
\hline & \multirow{2}{*}{ West Barcelona } & Soler Sauret & 1998 & 4 & No \\
\hline & & Soler Sauret & 2008 & 3 & Yes \\
\hline \multirow{3}{*}{$\begin{array}{c}\text { Negotiated } \\
\text { performance- }\end{array}$} & U1 & Mohn (Baixbus) & & & \\
\hline & $\mathrm{U} 2$ & Oliveras (Baixbus) & & & \\
\hline & Barcelona South Coast & Mohn (Baixbus) & & & \\
\hline based & $\begin{array}{c}\text { West Barcelona } \\
\text { (Night) }\end{array}$ & Mohn (Baixbus) & & & \\
\hline
\end{tabular}

Source: Based on documentation from the tendering processes. 
Table A2. Second order coefficients-Battese and Coelli specifications (standard errors in parentheses).

\begin{tabular}{|c|c|c|c|c|}
\hline & \multicolumn{2}{|c|}{ Dep. variable without transaction costs } & \multicolumn{2}{|c|}{ Dep. variable with transaction costs } \\
\hline & (1) & (2) & (3) & (4) \\
\hline \multirow{2}{*}{$\beta_{\mathrm{Y}^{\prime}}$} & $-0.019 * *$ & $-0.019 * *$ & $0.042 * *$ & $0.048 * * *$ \\
\hline & $(0.009)$ & $(0.008)$ & $(0.018)$ & $(0.016)$ \\
\hline \multirow{2}{*}{$\beta_{\mathrm{N}^{\prime}}$} & $0.006^{*}$ & $0.008 * *$ & 0.000 & 0.004 \\
\hline & $(0.003)$ & $(0.003)$ & $(0.049)$ & $(0.0500)$ \\
\hline \multirow{2}{*}{$\beta_{\mathrm{SP}^{\prime}}$} & $0.132 * * *$ & $0.132 * * *$ & 0.110 & 0.104 \\
\hline & $(0.005)$ & $(0.005)$ & $(0.083)$ & $(0.101)$ \\
\hline \multirow{2}{*}{$\beta_{\mathrm{PL}^{\prime}}$} & $0.161 * * *$ & $0.162 * * *$ & -0.019 & -0.020 \\
\hline & $(0.004)$ & $(0.004)$ & $(0.335)$ & $(0.033)$ \\
\hline \multirow[t]{2}{*}{$\beta_{\mathrm{K}^{\prime}}$} & $-0.078 * *$ & $-0.071 *$ & -0.086 & -0.060 \\
\hline & $(0.039)$ & $(0.038)$ & $(0.056)$ & $(0.089)$ \\
\hline \multirow[t]{2}{*}{$\beta_{\mathrm{YN}}$} & 0.000 & 0.001 & $-0.164 * * *$ & $-0.164 * * *$ \\
\hline & $(0.006)$ & $(0.006)$ & $(0.031)$ & $(0.058)$ \\
\hline \multirow[t]{2}{*}{$\beta_{\mathrm{YSP}}$} & $-0.033 * *$ & $-0.034 * * *$ & $0.074 * * *$ & 0.077 \\
\hline & $(0.013)$ & $(0.012)$ & $(0.019)$ & $(0.090)$ \\
\hline \multirow[t]{2}{*}{$\beta_{\mathrm{YPL}}$} & 0.001 & -0.002 & $0.033 * *$ & $0.029 *$ \\
\hline & $(0.006)$ & $(0.005)$ & $(0.016)$ & $(0.015)$ \\
\hline \multirow[t]{2}{*}{$\beta_{\mathrm{YK}}$} & $0.039 * *$ & $0.037 * *$ & 0.002 & -0.010 \\
\hline & $(0.019)$ & $(0.018)$ & $(0.026)$ & $(0.031)$ \\
\hline \multirow[t]{2}{*}{$\beta_{\mathrm{NSP}}$} & 0.003 & 0.004 & $0.138 * *$ & $0.135^{* *}$ \\
\hline & $(0.004)$ & $(0.004)$ & $(0.058)$ & $(0.057)$ \\
\hline \multirow{2}{*}{$\beta_{\mathrm{NPL}}$} & 0.001 & 0.000 & -0.002 & -0.004 \\
\hline & $(0.003)$ & $(0.003)$ & $(0.021)$ & $(0.027)$ \\
\hline \multirow{2}{*}{$\beta_{\mathrm{NK}}$} & -0.001 & -0.005 & $0.273 * * *$ & $0.269 * *$ \\
\hline & $(0.012)$ & & $(0.059)$ & $(0.111)$ \\
\hline \multirow{2}{*}{$\beta_{\mathrm{SPK}}$} & $0.063 * *$ & $0.064 * * *$ & $-0.200 * * *$ & -0.204 \\
\hline & $(0.026)$ & $(0.024)$ & $(0.047)$ & $(0.171)$ \\
\hline \multirow{2}{*}{$\beta_{\text {SPPL }}$} & $-0.159 * * *$ & $-0.158 * * *$ & $-0.096 * * *$ & $-0.094 * *$ \\
\hline & $(0.006)$ & $(0.005)$ & $(0.035)$ & $(0.042)$ \\
\hline \multirow{2}{*}{$\beta_{\mathrm{PLK}}$} & 0.001 & 0.006 & $-0.107 * *$ & $-0.101 * *$ \\
\hline & $(0.012)$ & $(0.011)$ & $(0.041)$ & $(0.040)$ \\
\hline $\begin{array}{c}\text { Log } \\
\text { likelihood }\end{array}$ & 1728.33 & 1734.66 & 944.35 & 944.33 \\
\hline Observations & 378 & 378 & 378 & 378 \\
\hline
\end{tabular}

Significance levels: * 10 percent; $* * 5$ percent; $* * * 1$ percent 
Table A3. Second order coefficients on True Random Effects specifications (standard errors in parentheses).

\begin{tabular}{|c|c|c|c|c|}
\hline & \multicolumn{2}{|c|}{ Dep. variable without transaction costs } & \multicolumn{2}{|c|}{ Dep. variable with transaction costs } \\
\hline & (5) & (6) & (7) & (8) \\
\hline \multirow{2}{*}{$\beta_{Y^{\prime}}$} & $0.058 * * *$ & $0.020 * *$ & 0.094 & $0.118^{*}$ \\
\hline & $(0.0126)$ & $(0.0098)$ & $(0.0687)$ & $(0.0683)$ \\
\hline \multirow{2}{*}{$\beta_{\mathrm{N}^{\prime}}$} & 0.004 & 0.003 & 0.004 & 0.019 \\
\hline & $(0.0063)$ & $(0.0047)$ & $(0.0257)$ & $(0.0278)$ \\
\hline \multirow{2}{*}{$\beta_{\mathrm{SP}^{\prime}}$} & $0.113 * * *$ & $0.127 * * *$ & $0.130 * * *$ & $0.130 * *$ \\
\hline & $(0.0120)$ & $(0.0072)$ & $(0.049)$ & $(0.0532)$ \\
\hline \multirow{2}{*}{$\beta_{\mathrm{PL}^{\prime}}$} & $0.173 * * *$ & $0.166^{* * *}$ & -0.001 & 0.005 \\
\hline & $(0.0083)$ & $(0.0055)$ & $(0.0319)$ & $(0.0333)$ \\
\hline \multirow[t]{2}{*}{$\beta_{\mathrm{K}^{\prime}}$} & $0.305 * * *$ & $0.110 * *$ & 0.169 & 0.323 \\
\hline & $(0.0523)$ & $(0.043$ & $(0.3121)$ & $(0.3106)$ \\
\hline \multirow[t]{2}{*}{$\beta_{\mathrm{YN}}$} & $0.100 * * *$ & $0.032 * * *$ & $-0.122 * *$ & $-0.096^{*}$ \\
\hline & $(0.0104)$ & $(0.0061)$ & $(0.0502)$ & $(0.0516)$ \\
\hline \multirow[t]{2}{*}{$\beta_{\mathrm{YSP}}$} & $-0.163 * * *$ & $-0.054 * * *$ & 0.046 & 0.0236 \\
\hline & $(0.0233)$ & $(0.0138)$ & $(0.0855)$ & $(0.0913)$ \\
\hline \multirow[t]{2}{*}{$\beta_{\mathrm{YPL}}$} & $-0.057 * * *$ & $-0.025 * * *$ & 0.000 & -0.027 \\
\hline & $(0.0115)$ & $(0.0067)$ & $(0.0467)$ & $(0.0425)$ \\
\hline \multirow[t]{2}{*}{$\beta_{\mathrm{YK}}$} & $-0.134 * * *$ & $-0.048 * *$ & -0.118 & -0.181 \\
\hline & $(0.0254)$ & $(0.0205)$ & $(0.1453)$ & $(0.1445)$ \\
\hline \multirow[t]{2}{*}{$\beta_{\mathrm{NSP}}$} & 0.003 & 0.006 & $0.128 * * *$ & $0.124 * * *$ \\
\hline & $(0.0075)$ & $(0.0060)$ & $(0.0345)$ & $(0.0365)$ \\
\hline \multirow{2}{*}{$\beta_{\mathrm{NPL}}$} & $-0.027 * * *$ & $-0.007 *$ & -0.012 & -0.022 \\
\hline & $(0.0050)$ & $(0.004)$ & $(0.0237)$ & $(0.0245)$ \\
\hline \multirow{2}{*}{$\beta_{\mathrm{NK}}$} & $-0.199 * * *$ & $-0.063 * * *$ & $0.198 * *$ & 0.142 \\
\hline & $(0.0197)$ & $(0.0124)$ & $(0.0973)$ & $(0.1005)$ \\
\hline \multirow{2}{*}{$\beta_{\mathrm{SPK}}$} & $0.325 * * *$ & $0.101 * * *$ & -0.138 & -0.092 \\
\hline & $(0.0466)$ & $(0.0279)$ & $(0.172)$ & $(0.1873)$ \\
\hline \multirow{2}{*}{$\beta_{\text {SPPL }}$} & $-0.137 * * *$ & $-0.160 * * *$ & $-0.098 * *$ & $-0.101 * *$ \\
\hline & $(0.0095)$ & $(0.0060)$ & $(0.0391)$ & $(0.0424)$ \\
\hline \multirow{2}{*}{$\beta_{\mathrm{PLK}}$} & $0.124 * * *$ & $0.054 * * *$ & -0.042 & 0.016 \\
\hline & $(0.0231)$ & $(0.0143)$ & $(0.0967)$ & $(0.0883)$ \\
\hline$\lambda=\sigma_{\mathrm{u}} / \sigma_{\mathrm{v}}$ & 1.288 & 0.163 & $1.997 * * *$ & 2.879 \\
\hline Log likelihood & 1532.50 & 1765.69 & 951.24 & 953.22 \\
\hline Observations & 405 & 405 & 405 & 405 \\
\hline
\end{tabular}

Significance levels: * 10 percent; ** 5 percent; $* * * 1$ percent 
Table A4. Second order coefficients_-Battese and Coelli and True Random Effects model being dependent variable with transaction costs by passengers (standard errors in parentheses).

\begin{tabular}{|c|c|c|c|c|}
\hline & \multicolumn{4}{|c|}{ Dependent variable with transaction costs by passengers } \\
\hline & \multicolumn{2}{|c|}{ Battese and Coelli (1992) } & \multicolumn{2}{|c|}{ True Random Effects model } \\
\hline & (13) & (14) & $(15)$ & (16) \\
\hline \multirow{2}{*}{$\beta_{Y^{\prime}}$} & 0.024 & -0.069 & -0.015 & 0.046 \\
\hline & $(0.0275)$ & $(0.0441)$ & $(0.0785)$ & $(0.0553)$ \\
\hline \multirow{2}{*}{$\beta_{\mathrm{N}^{\prime}}$} & -0.021 & 0.029 & $0.056 * * *$ & $0.033 *$ \\
\hline & $(0.0175)$ & $(0.0175)$ & $(0.0209)$ & $(0.0179)$ \\
\hline \multirow{2}{*}{$\beta_{\mathrm{SP}^{\prime}}$} & $0.137 * * *$ & 0.037 & 0.087 & 0.052 \\
\hline & $(0.0225)$ & $(0.0258)$ & $(0.0566)$ & $(0.0412)$ \\
\hline \multirow{2}{*}{$\beta_{\mathrm{PL}^{\prime}}$} & $0.146 * * *$ & $0.185 * * *$ & $0.202 * * *$ & $0.194 * * *$ \\
\hline & $(0.0116)$ & $(0.0195)$ & $(0.0393)$ & (0.0309) \\
\hline \multirow{2}{*}{$\beta_{\mathrm{K}^{\prime}}$} & $0.220^{*}$ & 0.282 & -0.066 & 0.190 \\
\hline & $(0.1171)$ & $(0.1926)$ & $(0.2978)$ & $(0.2114)$ \\
\hline \multirow{2}{*}{$\beta_{\mathrm{YN}}$} & $0.035^{*}$ & 0.000 & -0.006 & 0.009 \\
\hline & (0.0199) & $(0.0292)$ & $(0.0376)$ & $(0.0269)$ \\
\hline \multirow{2}{*}{$\beta_{\mathrm{YSP}}$} & 0.048 & 0.100 & -0.055 & 0.031 \\
\hline & $(0.0379)$ & $(0.0633)$ & $(0.1016)$ & $(0.0824)$ \\
\hline \multirow{2}{*}{$\beta_{\mathrm{YPL}}$} & -0.003 & 0.019 & 0.009 & 0.022 \\
\hline & $(0.0167)$ & $(0.0279)$ & $(0.0525)$ & $(0.038)$ \\
\hline \multirow[t]{2}{*}{$\beta_{\mathrm{YK}}$} & -0.082 & -0.140 & 0.031 & -0.093 \\
\hline & $(0.0564)$ & $(0.0916)$ & $(0.1524)$ & (0.1077) \\
\hline \multirow{2}{*}{$\beta_{\mathrm{NSP}}$} & 0.011 & 0.012 & -0.068 & -0.001 \\
\hline & $(0.0135)$ & $(0.0185)$ & $(0.0286)$ & $(0.0223)$ \\
\hline \multirow{2}{*}{$\beta_{\mathrm{NPL}}$} & -0.005 & -0.026 & -0.020 & $-0.032 *$ \\
\hline & $(0.010)$ & $(0.0138)$ & $(0.0188)$ & $(0.0164)$ \\
\hline \multirow{2}{*}{$\beta_{\mathrm{NK}}$} & -0.060 & -0.012 & -0.003 & -0.028 \\
\hline & $(0.0367)$ & $(0.0569)$ & $(0.0723)$ & $(0.0520)$ \\
\hline \multirow{2}{*}{$\beta_{\mathrm{SPK}}$} & -0.095 & -0.207 & 0.110 & -0.063 \\
\hline & $(0.0740)$ & $(0.1257)$ & $(0.2029)$ & $(0.1629)$ \\
\hline \multirow{2}{*}{$\beta_{\mathrm{SPPL}}$} & $-0.142 * * *$ & $-0.241 * * *$ & $-0.158 * * *$ & $-0.206 * * *$ \\
\hline & $(0.0159)$ & $(0.0269)$ & $(0.0471)$ & $(0.0418)$ \\
\hline \multirow{2}{*}{$\beta_{\mathrm{PLK}}$} & 0.010 & -0.006 & 0.002 & -0.012 \\
\hline & $(0.0338)$ & $(0.0576)$ & $(0.1061)$ & $(0.0779)$ \\
\hline$\lambda=\sigma_{\mathrm{u}} / \sigma_{\mathrm{v}}$ & 79.59 & 0.05 & $3.828 * * *$ & $2.015 * * *$ \\
\hline Log likelihood & 1275.71 & 1127.25 & 1101.58 & 1142.51 \\
\hline Observations & 378 & 378 & 405 & 405 \\
\hline
\end{tabular}

Significance levels: * 10 percent; $* * 5$ percent; $* * * 1$ percent 


\title{
Endnotes
}

\begin{abstract}
${ }^{1}$ In their study of local public services, Brown and Potoski (2005) examined operation and maintenance costs and ranked bus systems 27 th out of 64 services in terms of service measurability (the lower the ranking, the easier to measure the service) and 39th in terms of asset specificity (the lower the ranking, the lower the specificity). Similarly, Hefetz and Warner (2012) ranked bus system maintenance 29th out of 67 services in terms of asset specificity and 35th in terms of contract management difficulty (the lower the ranking, the lower the difficulty). All in all, Girth et al. (2012) classify bus systems as lying somewhere between monopoly and low competition services.
\end{abstract}

${ }^{2}$ Several studies have focused solely on regional services or on mixed urban/regional services (e.g., Fazioli, Filippini, \& Prioni, 1994) and so are not directly comparable to our study.

${ }^{3}$ In Germany there is an incumbent renewal rate of 74 percent and an average of more than five bidders per tender (Beck \& Walter, 2013). The relationship between buyer and vendor evolves over time, and the dependence of one party on the other grows. Local governments tend to place greater trust in the faithfulness and honesty of their vendors when the latter party has a known reputation from prior to the relationship, strong community ties, and performs its tasks well (Lamothe \& Lamothe, 2012). Thus, welfare gains from extending contract length can be relevant but accrue mostly to operators (Gagnepain, Ivaldi, \& Martimort, 2013).

${ }^{4}$ Note, however, potential unintended effects of high-powered, performance-based contracts have been found in some services (Koning \& Heinrich, 2013), where these contracts can mean not providing a service to the hard-toserve clients.

${ }^{5}$ Another public agency, Autoritat Metropolitana del Transport (ATM), is responsible for setting fares for all transport modes. Since 2002 an integrated fare policy exists for all public transport supply with the exception of the airport shuttle bus and the city tour bus. The integrated fare system implies that the different modes of transport (metro, bus, train, and light-rail) can be used with a single travel card. All lines in our database have the same fare. ${ }^{6}$ However, in 2011 a joint venture group formed by TMB and Vectalia (a private group based in Valencia) was awarded the provision of public transport in the Perpignan Méditerranée Metropolitan Area (France).

${ }^{7}$ All appendices are available at the end of this article as it appears in JPAM online. Go to the publisher's website and use the search engine to locate the article at http://onlinelibrary.wiley.com.

${ }^{8}$ The weight of the financial proposal represents between 25 and 30 percent of the total valuation of the bid. Greater weighting is attached to characteristics of the bids other than the financial proposal (required subsidy), including experience in the sector, expected ridership, or staff and equipment used. As a result, incumbents almost always obtain higher valuations in the non-financial aspects of the bid, which allows them to retain the contract. A more recent tender took place in 2013, but it is not included here, as the new contract did not come into operation until January 2014. Again, the incumbent retained the service.

${ }^{9}$ For instance, see Farsi, Filippini and Kuenzle (2006), Filippini and Prioni (2003), Fraquelli, Piacenza and Abrate (2004), Matas and Raymond (1998), and Ottoz, Fornengo and Di Giacomo (2009). The translog cost function considers cost as a function of input prices and the production level. This flexible functional form is a secondorder logarithmic approximation to any arbitrary twice-differentiable cost function. The values of the explanatory variables are normalized to the mean. We assume that input prices and output are exogenous, and that the cost function is the result of cost minimization given input prices and output.

${ }^{10}$ The inclusion of average speed may imply strong correlations with other explanatory variables. We obtained correlations between output and network length and average speed of 0.28 and 0.36 , respectively. Both variables are included in the estimation.

${ }^{11}$ Recall that these costs are internalized by the firms in the bid that they make. Therefore, they constitute another item in the company's costs.

${ }^{12}$ We divide the regulator's total budget by the total number of lines (tender as well as performance-based contract lines, given that the regulator devotes effort to the performance-based contracts). When applying the new criteria for allocating transaction costs (number of passengers carried per line), we divide the regulator budget by the number of passengers. Here again we take into account all lines (including those with performance-based contracts).

${ }^{13}$ We are aware that by using lines as units of observation we are assuming the strict separability of each line operated by an individual transit system. In fact, we need to use the lines as observations as we only have four firms providing services in our analysis. It would be more realistic to assume that firms choose inputs on a firmwide basis to minimize costs, which would mean considering each company in a particular year as an observation. We use two different specifications, the second one including a dummy for each private firm, in order to control for firm's specificities. Note that our results are the same in both specifications (either with a dummy indicating private firm, or with a dummy for each private firm).

${ }^{14}$ All appendices are available at the end of this article as it appears in JPAM online. Go to the publisher's website and use the search engine to locate the article at http://onlinelibrary.wiley.com. 
${ }^{15}$ This wide span of results might be due to the fact that our unit of observation is "line" rather than "firm" or "city" (as usually happens in other studies).

${ }^{16}$ All appendices are available at the end of this article as it appears in JPAM online. Go to the publisher's website and use the search engine to locate the article at http://onlinelibrary.wiley.com.

${ }^{17}$ Even if that is beyond the main objectives of our analysis, we have been able to calculate scale and density economies. The parameter for scale economies does not suggest potential cost savings from extending the length of the lines. Regarding economies of density, we obtain the same trends and results. There are not differences between public values and private values; therefore, our analysis comparing public and private cost does not suffer from any distortion from this issue. Results are available upon request.

${ }^{18}$ For Battese and Coelli (1992) without transaction costs, we obtain very small inefficiency scores, but we still find statistically significant differences between public and private.

${ }^{19}$ All appendices are available at the end of this article as it appears in JPAM online. Go to the publisher's website and use the search engine to locate the article at http://onlinelibrary.wiley.com.

${ }^{20}$ In this regard, we note that a limitation of our analysis is that we do not have access to detailed information on quality indicators such as punctuality, perceived quality, etc. Given that the regulator can impose stricter obligations on quality in private firms, this could bias the costs of private firms upward. We thank a referee for this insight. 